\title{
Agricultural districts in the Italian regions: looking toward 2020
}

\author{
Daniela Toccaceli
}

\section{Correspondence:}

daniela.toccaceli@unifi.it

Department of Science for

Economics and Business,

University of Florence Via delle

Pandette, 9 I-50127Florence

\section{Springer}

\begin{abstract}
Agricultural, quality agro-food, supply-chain and rural districts were introduced by Italian law in 2001. With reference to European structural policies, especially rural development policy, and to the districts' originality and relationship to the LEADER method and programmes, we wonder whether they can still form a useful part of the new programming period 2014-2020. The question is analysed in the wider context of international literature on socio-economic and economic policy, so as to stimulate broader interest, with a view to the future. A survey on national scale is presented, limited to the districts legally recognised by the Regions. A detailed historical reconstruction is given, offering a 'reconstructive reading' through which we clarify the actual nature of these districts, including their connections to clusters and industrial districts. We also discuss how to better link the theoretical and the legal frameworks. And we examine the connection between the basic economic mechanisms of the district theory and how the Regions have implemented them in reality. To do this, we summarised the overall conceptual framework into a few basic components for our desk research. This has led to development of a methodological definition of districts in agriculture.

Finally we give a concise analysis of the main outlines of the structural policies relating to this essential notion of 'district', in order to reach some conclusions of general validity.

Keywords: Agricultural; Quality agro-food; Supply-chain and rural districts; Industrial districts; Cluster; Business network; LEADER method; Rural governance and multi-level governance; Rural development policy; European structural and investment funds; Community-led local development; Italian Regions
\end{abstract}

\section{Background}

The new approach for European structural policy for the period 2014-2020 gives the local scale a strategic role in implementing interventions in support of participatory local development. This is to be based upon multi-level governance (Committee of the Regions 2009) and expansion of the LEADER method, especially in order to implement community-led local development (CLLD) and multi-fund strategies (European Commission's Directorates General AGRI, EMPL, MARE and REGIO 2013, European Union 2013:357-359).

In Italy the Regions ${ }^{\mathrm{a}}$ are responsible for implementing these policies through their own programming and for integrating them using other policy tools. Many Regions had already recognised agricultural districts under the Italian law of $2001^{\mathrm{b} .}$ that empowered

(C) 2015 Toccaceli; licensee Springer. This is an Open Access article distributed under the terms of the Creative Commons Attribution License (http://creativecommons.org/licenses/by/4.0), which permits unrestricted use, distribution, and reproduction in any medium, provided the original work is properly credited. 
them to identify Districts in Agriculture ${ }^{\text {c. }}$ (DAs) in the form of rural or quality agro-food districts.

At the time of its introduction, that law aimed to boost agricultural modernisation, following the new deal promoted by Agenda 2000. Today, with the new programming cycle of European structural policies and common agricultural policy, the important question is, how useful are the DAs and how can they be inserted into the new regional programming framework in order to implement rural development programmes?

Despite many studies into regional experiences of DAs ${ }^{\mathrm{d}}$, organic knowledge is still lacking about implementation of the law on a national level, which is still ongoing. Indeed, researching on a national scale has proved very complex for three reasons: i) DAs have become very different "things" in each regional interpretation, so it is difficult to make comparisons among them; ii) DAs are still an open chapter of economic and agricultural research, because of the particular theoretical framework that has been adopted in Italy; iii) the theoretical and legal frameworks are still not fully integrated (Musotti 2001b).

We have addressed these difficulties by reconstructing the legislative situation stratified over a twenty-year period - the 'reconstructive reading' according to Albisinni (2010) - and by using a fresh approach. Our research aims to create the conditions for comparing experiences which have arisen in concurrence with very different regulatory frameworks and political contexts. Our article also tries to recreate an updated geographical mapping of the phenomenon at national level and seeks to outline the main economic attributes assumed by DAs. On the basis of our findings we offer our initial thoughts on the potential and weaknesses of future use of DAs in the coming programming period 2014-2020.

Although this article focuses on Italian agricultural, quality agro-food, supply-chain and rural districts, the issue is placed in the context of international socio-economic literature on the subject. The research may thereby be of more general interest, firstly because clusters and industrial districts are widespread at global level in the agricultural sector and also because of the original approach used for analysing regional policies.

Some different instruments, similar to DAs even if not derived from a 'district' concept, exist in other European countries, as mentioned below.

\section{A brief literature review of clusters and Marshallian Industrial Districts}

Agglomerations of companies closely interconnected, specialised and co-located in a specific place have been the subject of empirical observations and researches over many years and in many countries. The earlier Marshallian Industrial District (MIDs) notion originated what is nowadays considered the core of the theoretical framework for explaining their persistence and diffusion: external economies and "industrial atmosphere" (Becattini et al. 2009). Though they have changed over time, they have been noted because of their success as well as, sometimes, for the excellent reputation of some product-place associations and specialisations, for example the "Prosciutto di Parma".

According to Becattini et al. (2009) and Porter and Ketels (2009), clusters and MIDs are neither synonyms nor concepts conceived in same scientific context or with reference to identical economic and societal environments, although they have "common roots". 
Coming from a business strategy approach (Porter 1998) to understand the determinants of competition, Porter and Ketels (2009) define clusters as "geographic agglomerations of companies, suppliers and service providers, and associated institutions in a particular field, linked by externalities and complementarities of various type" (2009:172). These authors consider them "by design, a broader concept and a more general one" (2009:182) than MIDs, which are instead considered as "one type of a cluster".

Conversely, Becattini's MIDs are defined as "socio-territorial entities characterised by the active presence of both a community of people and a population of firms in one naturally and historically bounded area with a dominant industrial activity" (Pyke et al. 1990, cit. in Porter and Ketels 2009:172). Becattini adds, however, that "the population of firms and the related market institutions are only one, though central, part of it" (Becattini et al. 2009: xviii) and consequently clusters are considered only the industrial core of a more complex district process.

For the purpose of this paper, it is worth underlining one significant difference and some essential, common key points.

While the concept of MIDs is strictly related to industrial manufacturing sectors as well as to a system of small-medium enterprises, the notion of cluster is "by design" recognised in any production or services sector (Porter 1998). So agricultural clusters are identified in rural regions, are studied with the same methodological approach and are involved in identical considerations about their role in the value chain and about public policies (Porter 2003; Porter et al. 2004; Feser and Isserman A. 2009). Instead, justifying the translation of the MID concept to agriculture has required great efforts on the part of Italian researchers, as discussed below.

In any case, both converge on these issues: i) the core of the theoretical framework rests on a few basic conceptual nodes: the proximity (spatial dimension) of companies and institutions, interrelated in vertical, horizontal and diagonal ways, allows for better organisation of the value chain (business dimension); more added value is provided by a special local mix of externalities resulting from (in MID terminology) industrial atmosphere or (in cluster terminology) business environment (socio-economic dimension); ii) both put at the core of their conceptual construction the strategic function of the relationships between companies, local institutions in a wide sense, and the governance mechanisms for better management of those relationships; at the same time both recognise the twofold presence of an internal (local) network as well as of an external network, each playing an important role in the district process (network and organising dimension); iii) both are positively correlated with local development processes and not only to the growth of the enterprises involved; iv) for both, researchers have addressed policy recommendations aimed at supporting their growth and the development of the place/ region where they are located (policy dimension).

So, clusters and MIDs are recognised in many countries which have introduced specific policies.

In the discussion of the results we analyse how these basic components work together in the Italian regional patterns. 


\section{Cluster policy approaches}

Porter (2003) survey on economic performance of U.S. regions claims that regional development policies have to be particularly attuned to traded clusters because of their capability to support higher wages but also because they drive local employment and affect regional economic performances. On the other hand, Feser and Isserman A. (2009) found that rural clusters play an important role in the national value chain. They maintained that public policies should support these clusters, not only to sustain rural development but also to achieve an overall goal of regional and national economic development. Still focusing on rural regions in the U.S., Porter et al. (2004) state the importance of "cluster thinking" in rural economic development, remarking that policy has to be set at local and regional level because of the heterogeneity of rural areas and that community-based planning is needed. A "cluster-based approach" is thought essential for involving the private sector, and an "overarching organisational structure" for economic development is deemed helpful to coordinate and drive the process. However, they note, the role of institutions in a wider sense in the process of economic development in rural areas requires further research to be better understood.

In many European countries cluster policies - including industrial district policies have existed since the 90s. They have been addressed to systems of small and medium enterprises in various production sectors, as well as to networks in the cluster, either for developing them or sometimes for using a "cluster lens" to boost other instruments e.g. for innovation processes or regional development. An Oxford Research (2008) found it difficult to identify a clear pattern among the 27 countries investigated. The complex nature of a cluster entails that cluster policies are complex too, given their multiple dimensions and the multiple actors involved in the process of programming and implementing the policies. An important reason for this is that the structural policies of the European Union have come to be delivered through multi-level governance processes involving both local actors and, vertically, more distant subjects and administration levels. Meanwhile, principles of subsidiarity and proportionality ${ }^{\mathrm{e}}$ were entering the political and legal systems and processes of decentralisation towards the most peripheral levels of administration were occurring in many countries, Italy included.

Borràs and Tsagdis (2008) recognised five types of cluster policy, ranging from three top-down types that aim to create clusters from scratch ('creationist') or to support them without encompassing a bottom-up process ('narrow' and 'top-down'), to the two more complex types: the 'evolutionary' one that considers clusters tend to evolve in a cumulative and gradual way and policy is embedded in the network which shapes the direction of these changing dynamics, and the 'network' policy. The latter is based on multi-level governance because it recognises that the role of public authorities is inscribed into a relationship between private and public actors in the territory where they try to solve problems collectively. 'Network' policy is confident not only regarding success by public authorities but also the strength of the network.

\section{And other related policies for rural areas in Europe}

In European rural areas some other policies have been implemented that involve the concepts of cluster and districts, in their approaches based on the concept of network, territorial value and governance, and their focus on innovation in the rural environment. In 
this paper we consider only policies for qualifying agriculture and agro-food products and on LEADER ${ }^{\text {f. }}$ programmes and methods. Although not cluster-specific, these policies have played a specific role in the integrated mix of main policies implemented in those areas, especially with reference to the rural districts and the quality agro-food districts which have developed in Italy, as further discussed below.

Stemming from the 1988 reform of structural funds, several LEADER programmes have developed continuously, undergoing various adjustments and growing in importance in the scope of rural policies, until they became integrated in rural development programmes in the past and in the current period. This was done without changing the basic methodological principle to which the specific 'LEADER added value' is attributed: bottom-up approach, territorial and integrated approach to rural development, public-private partnership in local action groups (LAGs), territorial networking and transnational cooperation to stimulate rural innovation processes. In other words, LEADER is a "network policy" in the sense that it looks at different types of networks with a multi-purpose intent. Firstly, at the 'social' network, which addresses the intangible factor of development through reinforcing the sense of local identity of the rural population, as well as the external image of the territory. This boosts marketing of local products (Ray 1998), because in LEADER a thread connects the sociological entity 'community' and the geographical entity 'territory' "that can be linked with an identifiable cultural heritage and identity" (Lee et al. 2005:275), as can the socio-economic entity 'social capital'. Secondly, the 'horizontal' network, as Murdoch (2000) put it, "linked to more general and also non-agricultural processes", which aims at integrated development of rural economy in a defined area. Thirdly, the 'vertical' network, which links actors of a specific area because of their involvement in the agro-food sector (Murdoch 2000).

Governance is therefore a fundamental process for the success of this policy, which has often attracted criticism about its capability to concretely and effectively achieve the prefigured added value (European Court of Auditors 2010).

For several years voluntary certification schemes have been in use in Europe ${ }^{\mathrm{g} .}$ offering protected status to foodstuffs with a certified local identity. This is a mechanism for adding value to such foods, thereby aiding local economies and supporting to some extent rural development (Tregear et al. 2007). In these policies too, it is the role of network and governance that is interesting for our purposes. Regarding the designation of origin supply chains (filière) Perrier-Cornet and Sylvander (2000) focus, firstly, on the development of collective strategies through coordination by filière actors in various ways. The aim of these strategies is to gain a collective, competitive advantage linked to a specific place and shared ways of working and traditions. This advantage depends on quality territorial revenue (Pecqueur 2001; Mollard 2001). Secondly, they discuss the more complex territorial strategies developed using various mixes of sectorial and territorial governance related to different degrees of territorial anchorage of the supply chains.

The overlap seems self-evident between the two types of European policies directed at farms and agro-food business supply chains, which sometimes may be spatially concentrated in local systems, if not coinciding with a recognised district. Sforzi and Mancini (2012), however, suggest it is worth bearing in mind the difference between a 'simple' localised agro-food system (Courlet and Pecqueur 1992) and a district, which 
implies a socioeconomic process (local community involvement) that is not present in the former.

Finally, worth mentioning is comparative research (Pacciani and Toccaceli 2014; Toccaceli 2014) into some case studies in several European member states, seeking to identify methodological analogies between DAs and other instruments developed to manage rural governance. This found considerable similarities with the French contrat de Pays (Toccaceli 2012:28) and the functioning of the collectivités territoriales (Rouger 2014), as well as with other systems in Belgium (Collignon 2014) and LEADER-based experiences in Spain (Gallego Moreno 2014).

\section{DAs in the debate by Italian agricultural economists}

In Italy the MID notion began to be applied to the agricultural sphere from the end of the ' 80 s, as a result of contamination between industrial and agricultural economists (Angeli 2000), in a context both of visible change in agricultural structure and of progressive differentiation of production in the countryside. Meanwhile, European rural development policy started to be formulated with the European Commission's communication “The Future of Rural Society" (Commission of the European Communities 1988). In Italy, Iacoponi (1990) began ${ }^{\text {h. }}$ by putting the question as simply an extension to agriculture of the Marshallian district concept re-elaborated by Becattini $(1987,1989)$ for Italian industrial districts.

However, the debate soon became an occasion for rethinking (and disputing) the comparison between "two opposite economic paradigms" 1992; Becattini 2000 and Becattini 2001; Iacoponi 2001): the neoclassical and the districtual. As a result, the "systemic" stream of economic agricultural thought was revisited, deriving from the "territorial" approach (De Benedictis 2000; De Filippis 2000, Fabiani 2000; Angeli 2000; Musotti 2001a) observing that "the reality was beginning to escape the theory"” (Favia 2000). But only some agricultural economists were willing to welcome the 'district' paradigm, so limited but essential contributions referring to the notion of agricultural district were produced.

Iacoponi (2001) considered the paradigm of the industrial district proposed by Becattini to be composed of two core concepts, interacting dynamically in the local district system: the production-organisational (typically Marshallian) and the socioeconomic (typically Becattinian). Such an artificial separation is useful in neatly clarifying the different notions of districts in agriculture: the agro-industrial district and the agricultural district, both related to the production-organisational approach (Iacoponi 1990, Cecchi 1992); and the rural district that better reflects the socio-economic approach (Romano 2000; Iacoponi 2002).

\section{The notions of agricultural district and agro-industrial district}

Iacoponi based his assessment of the compatibility between industrial and agro-industrial districts on a theoretical elaboration aimed at reconnecting the company-oriented economic approach typical of economic agrarian tradition, with the "contribution of the modern theory of the firm and developing it in such a direction as to include production systems organised at the local level*" (1990:711). According to an integrated vision of agriculture (Casati 1988) he took into account the overall production structures of agriculture and observed that only few farms are autonomous from an 
organisational point of view (1990). All the others are integrated either into the general economic system of the territory, or into the agro-industrial system. In the latter case, depending on the agribusiness structure, integration can be either at the level of the local system of enterprises (agricultural district), or at the level of product market (supply-chain integration), or at the level of the local system of firms and product markets (agro-industrial district). As an example of agro-industrial district Iacoponi cited the case of Parmigiano Reggiano.

Cecchi accepted Iacoponi's idea and elaborated it with more attention to the farms' territorial value. He therefore argued that: "The designation of agricultural district has to be found in the centrality of agricultural production: that is, it must be able to identify local agriculture as the "engine" of a district; so even in the presence of agro-industrial activities, the latter exists and thrives because it represents a processing of local agricultural products"” (1992:96). As an example of agricultural district he cited the Chianti wine district. He then goes on to provide a definition of agro-industrial district, which is when "the main distinguishing element is represented by the fact that the processing industry will use mainly agricultural products from outside the district itself"" (1992:97). The example referred to is the Po milk chain, which (evolving from an agricultural district) transforms milk mainly from external sources.

\section{The notion of rural district}

The rural district is analysed in relation to the various forms of socio-economic organisation that can characterise local systems in the countryside (Montresor 2000; Romano 2000; Forleo 2000). This covers not only areas where agricultural production is prevalent, but also local systems of rural development or peri-urban areas where production differentiation has not occurred (Cecchi 2000) or agro-districts and, lastly, rural districts. Cecchi described patterns of farm integration into the overall system of the territory, where the development of economic organisation solutions has enhanced the contextual knowledge and the capabilities of cooperation and social integration of local actors. He therefore distinguished "the districts of the areas of agricultural specialisation from those of rural local systems" (2000:125).

Consequently, rather than connect the rural to the Marshallian district, according to the basic principles set out by Becattini (2000), Cecchi uses the "district approach" to separate social processes from economic ones. He thus highlights their specific contribution to and support of production differentiation of the countryside and sees the consolidation of the rural economy as having a plurality of economic activities rather than a predominance of agriculture. On this basis, he asserts that the possibility of identifying rural districts rather than agro-industrial districts is "more likely", although it is not easy to "perceive" a rural district because of the greater "physical distance between people and businesses" (2000:128). He thereby underlines how the spatial concept of proximity is changeable in the rural context and very different from the industrial one, especially in relation to MIDs.

Iacoponi, on the other hand, states that "the hypothesis that rural development is a local, sustainable, integrated and endogenous development leads us to the concept of the rural district, which is derived from the concept of industrial district (Becattini 1987; Bellandi 1987) and agro-industrial district (Iacoponi 1990; Fanfani and Montresor 1998; 
Cecchi 1992; Favia 1992)."” (2002:74). Following Becattini's approach, he distinguishes firmly the notion of rural district from the weaker notion of a geographically significant network, because the first "is a strengthening and intensification of relations historically settled in the territory thanks to agriculture and activities related to them" (2000:76). In fact, he notes that the main character of a rural district is the ability to provide districtual synergies for the economic activities of small and medium enterprises which have a sporadic presence in the territory, where "the community market and the atmosphere of the rural district can perform the miracle of integrating the 'missing branches' of the local economy:" (2002:75-76), So Iacoponi highlights the basic socio-economic engine of the rural district.

Both scholars wrote taking as reference the case of the rural district of Maremma (Pacciani 1997; Pacciani 2002a and Pacciani 2003; Belletti and Marescotti 2004 and Belletti and Marescotti 2010; Pacciani and Toccaceli 2010; Toccaceli 2012) promoted by Pacciani in 1996. Pacciani bypassed the scientific debate to enter the experimental and operational dimension oriented towards planning and implementation of the rural district, in its first prototypal form. His approach was independent of the idea of "transposing" the notion of industrial district to agriculture. Rather, he reworked and combined certain elements in the political and cultural debate of the '90s, including the gradual strengthening of European rural development policy and local development support (De Rita and Bonomi 1998) to be pursued through specific instruments of negotiated planning (CNEL 1999; De Meo and Nardone 2002). Pacciani's contribution (Pacciani 2002b) is particularly significant because he suggested a conceptual link between the rural district and LEADER, just as strong as (if not stronger than) the one with Marshallian industrial districts.

For the economists mentioned above, it is self-evident that the overlap of the concepts of local and rural development in the notion of rural district is strictly linked to all the new functions of agriculture (economic, environmental and socio-cultural). Later both Quality Agro-Food Districts (DAQ) and Rural Districts (DIRU) came to be considered a positive response to the rapid development of globalisation (Tinacci Mossello 2002) which is pushing for the relocation of many industrial districts (Corò and Grandinetti 1999). DAs, by contrast, as a "nemesis of history" (especially quality agro-food districts, see De Rosa and De Vincenzo 2002:14), react by putting in place a strategy deeper rooted in the territory, conducted by enhancing typical products and multi-functionality of agriculture.

\section{The political approach in Italy}

Pacciani defines the rural district of Maremma "a complete implementation of the Cork Declaration"”, introducing it into the agrarian-economic debate as a "development model and method of governance" ${ }^{*}$ in rural areas (Pacciani 2003:48). In this sense, the rural district was also taken into account by the government.

With his formulation, Pacciani offers a response to the policy issues raised by Iacoponi and Cecchi. Iacoponi (1990) believes that the Common Agricultural Policy (CAP) should strengthen existing districts and encourage the growth of those new ones. Cecchi considers that regulatory measures will be perceived differently, as if through "filters", in different places and this implies the existence of a local demand 
for policies that should find a "strong political mediation, implemented on the basis of territorial articulation” (1992:88).

The issue of how such mediation may legitimately be conducted, although noted, was left open while in practice the rural district as a "method of governance" was already providing some local responses.

In 2001 the economic debate was bypassed by government intervention placing the DAs in the context of legislation regarding modernisation of agriculture $\mathrm{e}^{\mathrm{j}}$. This regarded DAs as new tools for increasing competitiveness of the primary sector according to European guidelines for reviewing the CAP and rural development policy.

Because of its pragmatic aim, the government only partially followed indications arising from the scientific debate, rather considering pilot experiences autonomously occurring in Maremma and Piedmont (Toccaceli 2012).

The government was particularly driven by the progressive intertwining of legislation on industrial districts and negotiated planning, whose applicability was extended to all sectors, including agriculture, thus opening the door to district legislation in that sector (Albisinni 2010, 2011a and Albisinni 2011b). In the legal rationale, in fact, the DAs - and particularly the rural districts - were also taking on a second, but not secondary, meaning as tools for supporting local development of rural areas.

The news was not welcomed unreservedly by a part of the scientific world. Although extensive preparatory work had been carried out, the final text does not appear to have fully taken it into account and Musotti (2001b) observed that this law would scarcely help in identifying and properly "recognising" the district situation.

The controversy highlighted a misconception that was implicit in national law and that was to become increasingly more evident in the regional laws. Economic theory had studied those districts that had formed spontaneously, therefore the law should enable their recognition. Instead, in a 'creationist' interpretation - well evident in several regional laws - the DAs were to become subjects to be set up for implementing policies at local level.

In this blurry legislative context, the Regions have made and are still making very different choices about timing, as well as about the definition and aims of DAs and the rules of implementation to be adopted.

\section{The DAs in National and Regional legislation}

Because DAs refer to a composite regulatory framework that was created over a twenty-year period, a "reconstructive reading" (Albisinni 2010) was needed to evaluate the complexity of the phenomenon and the political intentions behind it. Bearing in mind that interest in DAs in Italy ran parallel to the evolution of European rural development policy, the succession of national regulatory interventions might be seen as falling into three periods, corresponding to different political and economic approaches. (See Table 1).

The first period corresponds to the years between the first law on industrial districts in 1991 and the Law of Orientation of 2001. At this stage, the action of the government was inspired by the constant intertwining of the initial scientific debate on industrial districts and the possibility of their extension to agriculture, the progress of the 
Table 1 Evolutionary path of the European and Italian regulations referring to the DAs and related definitions

\begin{tabular}{|c|c|c|c|c|}
\hline \multirow{2}{*}{$\frac{\text { EU political references }}{\text { C.I LEADER (1988-2006) }}$} & \multicolumn{2}{|c|}{ Italian National laws } & \multirow{2}{*}{$\begin{array}{l}\text { Legal notions } \\
\text { Industrial Districts Law } 317 / 91 \\
\text { art.36 para.1 }\end{array}$} & \multirow{2}{*}{$\begin{array}{l}\text { Definitions } \\
\text { Local territorial areas with high concentration of small enterprises, with particular } \\
\text { reference to relationship between presence of enterprises and resident population, as well } \\
\text { as to production specialisation of enterprises as a whole. }\end{array}$} \\
\hline & $1991-2001$ & $\begin{array}{l}\text { First law on industrial } \\
\text { districts }\end{array}$ & & \\
\hline & & $\begin{array}{l}\text { Regulation of negotiated } \\
\text { planning }\end{array}$ & Negotiated planning L. 104/1995 & $\begin{array}{l}\text { Regulations agreed between public entities, or with competent public entity, and party or } \\
\text { parties, public or private, for implementation of different interventions related to a unique } \\
\text { development purpose that requires comprehensive assessment of activities pertaining to it. }\end{array}$ \\
\hline \multirow[t]{4}{*}{ EU Rural development policy } & & & 1998 Del. CIPE & Applicability of negotiated planning to rural, agricultural and fisheries districts \\
\hline & & $\begin{array}{l}\text { Second law on industrial } \\
\text { districts }\end{array}$ & $\begin{array}{l}\text { Local productive systems (LPS) } \\
\text { Law 140/99 art.6 para. } 8\end{array}$ & $\begin{array}{l}\text { Homogeneous productive contexts with high concentration of industrial enterprises and } \\
\text { specialisation of business systems }\end{array}$ \\
\hline & & The Orientation Law & $\begin{array}{l}\text { Rural districts Legislative decree } \\
228 / 2001 \text { art.13 para.1 }\end{array}$ & $\begin{array}{l}\text { Local production systems referred to in Article 36, paragraph 1, of Law of } 5 \text { October } \\
1991 \text { n. } 317 \text { [see first row above] and subsequent amendments with homogeneous } \\
\text { identity from a historical and territorial point of view arising from integration } \\
\text { between agricultural activities and other local activities, as well as production of } \\
\text { goods or services of particular specificity, consistent with traditions and natural } \\
\text { and territorial vocations. }\end{array}$ \\
\hline & & & $\begin{array}{l}\text { Quality agro-food districts } \\
\text { Legislative decree } 228 / 2001 \\
\text { art.13 para.2 }\end{array}$ & $\begin{array}{l}\text { Local production systems, including interregional, with significant economic presence } \\
\text { and productive interrelationship, and interdependence of farms and agri-food enterprises, } \\
\text { and one or more certified or protected products in accordance with applicable } \\
\text { Community or national regulations, or from traditional or typical products. }\end{array}$ \\
\hline \multirow[t]{3}{*}{ LEADER AXIS (2007-2013) } & $2002-2008$ & The Finance Law 2006 & $\begin{array}{l}\text { Productive Districts Law } \\
266 / 2005 \text { art.1 para. } 366\end{array}$ & $\begin{array}{l}\text { Free combinations of enterprises articulated territorially and functionally, aiming at } \\
\text { enhancing development of areas and sectors, improving effective organisation and } \\
\text { production, according to principles of vertical and horizontal subsidiarity, also identifying } \\
\text { ways of working with entrepreneurial associations. }\end{array}$ \\
\hline & & & & Freely accessible by industrial companies, services, tourism and agriculture and fisheries. \\
\hline & 2008-2013 & $\begin{array}{l}\text { Business networks and } \\
\text { network contracts }\end{array}$ & $\begin{array}{l}\text { Business network L.133/2008 } \\
\text { art.6bis }\end{array}$ & $\begin{array}{l}\text { Free aggregations of single production centres cohesive in unitary development of } \\
\text { industrial policies, also in order to improve their presence in international markets }\end{array}$ \\
\hline $\begin{array}{l}\text { Extension of LEADER method } \\
\text { to ESI FUNDS }\end{array}$ & $2014-2020$ & What role for the DAs? & & \\
\hline
\end{tabular}


negotiated planning experience (Adornato 2005; Pacciani 2003; Albisinni 2011a) and the acknowledgment of some pilot experiments.

The early definition of industrial district (Table 1) well represents the basic components of the scientific notion in the spatial, business and social dimensions. It is limited to the industrial sector and only thanks to the formulation of the local production system notion did it pave the way for the extension of the district into different areas, such as rural, agro-food and fisheries. Similarly, in that period, negotiated planning instruments were being extended to cover agriculture and fisheries, services and tourism. The concept of negotiated planning explains the purpose of the first tools used by the DAs and allows us to appreciate the coherence of the two approaches.

At the same time, with negotiated planning, it became evident that the local approach required the establishment of a new kind of governance and specific tools to bring together different levels of public administration and public with private bodies. These tools must have the sole purpose of identifying specific solutions to sustain strategic projects supporting endogenous development and employment. In the wake of these measures, the Law of Orientation in agriculture introduced two distinct definitions for rural and quality agro-food districts, while maintaining a strong link with the basic concept of Local Production Systems (LPS), defined as "the homogeneous productive contexts characterised by both a high concentration of industrial enterprises and the specialisation of business systems". These LPS "characterised by homogeneous identity from a historical and territorial point of view, arising from integration between agricultural activities and other local activities, as well as the production of goods or services of particular specificity, consistent with traditions and natural and territorial vocations" are qualified as Rural Districts (DIRU). The definition of Quality Agro-food Districts (DAQ), on the other hand, is given to those LPS "even interregional, characterised by significant economic presence and production interrelationship, and by interdependence of farms and agri-food enterprises, and by one or more certified or protected products in compliance with applicable Community or national regulations, or by traditional or typical products". Without contesting Musotti (2001b), one may observe that these definitions more or less mirror the main terms of the scientific debate.

In the second period (2002-2008) Italian law continued to mature intentions and purposes. The first decade of the adoption of districts and negotiated programming tools had responded to the objective of increasing employment by supporting endogenous local development processes. In the next period, attention reverted to focussing primarily on support for districtual firms in their processes of innovation, rationalisation of production, supply chain and internationalisation. So in the 2006 finance law the definition of 'district' was revised and reworked in terms of "free association of undertakings"".

This new approach opened the way to a season of measures aimed at expanding the range of administrative, fiscal and credit incentives and benefits in favour of district enterprises, finally assimilating and equalising all the different types (and also industrial and agricultural districts) in this new notion. It is worth underlining that this is the sole, albeit important, new feature. In moving from the former to the latter definition of district, the government changed political approach, placing more emphasis on the role of entrepreneurial and private initiative than on that of the State. Nonetheless, political discussion about districts changed much more than did the legal approach. In fact 
the legal definition of production district included - albeit unnecessarily - explicit reference to the two principles of subsidiarity, thereby reconfirming the reciprocity as well as the cooperation necessary between private and public initiatives. In other words, the introduction of this new definition was justified more by general political aims than by a new economic policy stance.

Moving forward in the wake of the political approach above, the third period - in 2008 - saw the first regulation of business networks, which were defined as free aggregations of "single production centres" having the network contract as a specific tool. The network is an important element of the wider category of "institution" and is a basic node in the district conceptual framework very significant for the policy approach (Borràs and Tsagdis 2008), from a scientific point of view. It may therefore be considered a more focused tool for strengthening the formation of the business network, spontaneously created by firms, thanks to face-to-face interaction, or informal deals or private contracts. Instead, in the political approach, this intervention is deemed the right way of meeting the need for a simpler and faster tool than the district, recognising the changing requirements of mature industrial districts that have significantly changed their relationship with their territory and the local dimension, because companies have adopted delocalisation strategies to better compete in the global market. Rather, DAs and networks should be considered different but integrable instruments.

Over time the government has reformulated several different notions of district in its successive acts without repealing the preceding ones. The Regions are thus able to choose from these notions or mix them according to their own aims and approaches and nowadays they have become a tangled stratification of multiple definitions.

In fact, each Region has regulated the DAs differently (Toccaceli 2012: 58), often creating a path towards the formula deemed best for its objectives through subsequent interventions designed to respond to multiple pressures - either the changing economic and political scene, or precise requests from the territories concerned to create a specific district or in order to respond swiftly to the flurry of initiatives from the government. For example, following the 2006 Finance Law, ten Regions have enacted laws on DAs, either introducing them from scratch or adapting existing rules to create the conditions for access to new benefits introduced, so as to ensure maximum support to businesses in the Region. Moreover the Regions, far beyond the simple "implementation" of national provisions, have generated a lot of new types of district, e.g. the "supply chain districts" introduced by Lombardy.

Consequently, the overall picture is a heterogeneous image, changing over time, which well reflects the constant and fervent work of the Regions, unceasing and still ongoing, so it is not easy to order such a miscellany.

Therefore, in order to compare regional patterns, it was first of all necessary to identify a truly common concept of DA, highlighting the economic mechanisms actually involved, but taking a different approach than the political and juridical ones.

\section{Method}

Reconstructing the conceptual framework from a historical, economic and legal standpoint was essential in order to correctly fix the baseline upon which to found a survey on a national scale. 
The scope of the survey was limited to the DAs set up in those Regions with a law in force and desk research focused only on the DAs recognised by them.

The methodology is articulated in two phases. The first phase deals with the desk research into the DAs to define their main common features on a national scale, to show how the basic economic mechanisms of the notion of 'district' were designed by the Regions. The second phase deals with an analysis of the possible integrated role of the DAs in the coming programming period.

The desk research is sub-articled, referring to the different objectives: on one hand, to create an updated map of the recognised DAs, on the other hand, to carry out a critical analysis of the complex of regional laws to clarify the very notions of 'district' used by Regions. The latter objective aims to better highlight how the basic economic mechanisms are shaped by the regions and whether their functioning is effectively ensured. Final considerations on these outcomes guided us to the methodological approach, thanks to which a common notion of DA is proposed.

As information about DAs in Italy is not collected, nor immediately accessible, the data used to build Figure 1 came from the official regional sources of information and from examination of the main bibliography on the subject.

All regional regulation since 1990 was collated and critically examined in order to learn the essential elements for developing a scheme usable for conducting comparative analysis of such complex regulatory frameworks (Toccaceli 2012: Appendix). Following this, we were able to highlight the few key elements of each law: the juridical definition of district elaborated or used (derived from those offered by the national laws) and the typologies covered; the purposes attributed to the law; the requirements for identifying DAs and the procedures for their recognition; the organisational models developed to regulate the relations between the different actors involved in districtual dynamics; how projects are planned and financed; how the interventions are monitored.

Critical reflection has suggested considering the juridical issue of clarifying and reducing to a strict number the possible DA typologies, separately from the economic question.

In order to illustrate the connection between the basic economic mechanisms of the district notion and how the Regions have shaped and implemented this mechanism, the overall conceptual framework has been split into its basic components. These are the spatial and value chain dimension, which together represent the economic engine and network making and governance, which together represent the socio-economic engine. All components, of course, work together producing external economies and business environment and generating growth both for businesses and for the Regions where they are located. Finally, there is the political dimension. In this analysis, any external economies generated are the outcome -and even the aim - of a good regulation, rather than an element directly susceptible of regulation.

The spatial and the value chain dimensions in regional legislation are shaped through the choice of how to identify DAs, which relate to localisation and concentration of activities, as well as to their specialisation and interconnection in an organised value chain.

The manifold nature of institutions involved in the district process, as well their relationships, are again outlined through the governance requirements for identifying DAs, as well as in the rules that prefigure a large number of organisation patterns. It is worth underlining that mostly the local network is regulated, perhaps intending a too 'localistic' conception of the district, as better analysed below. 


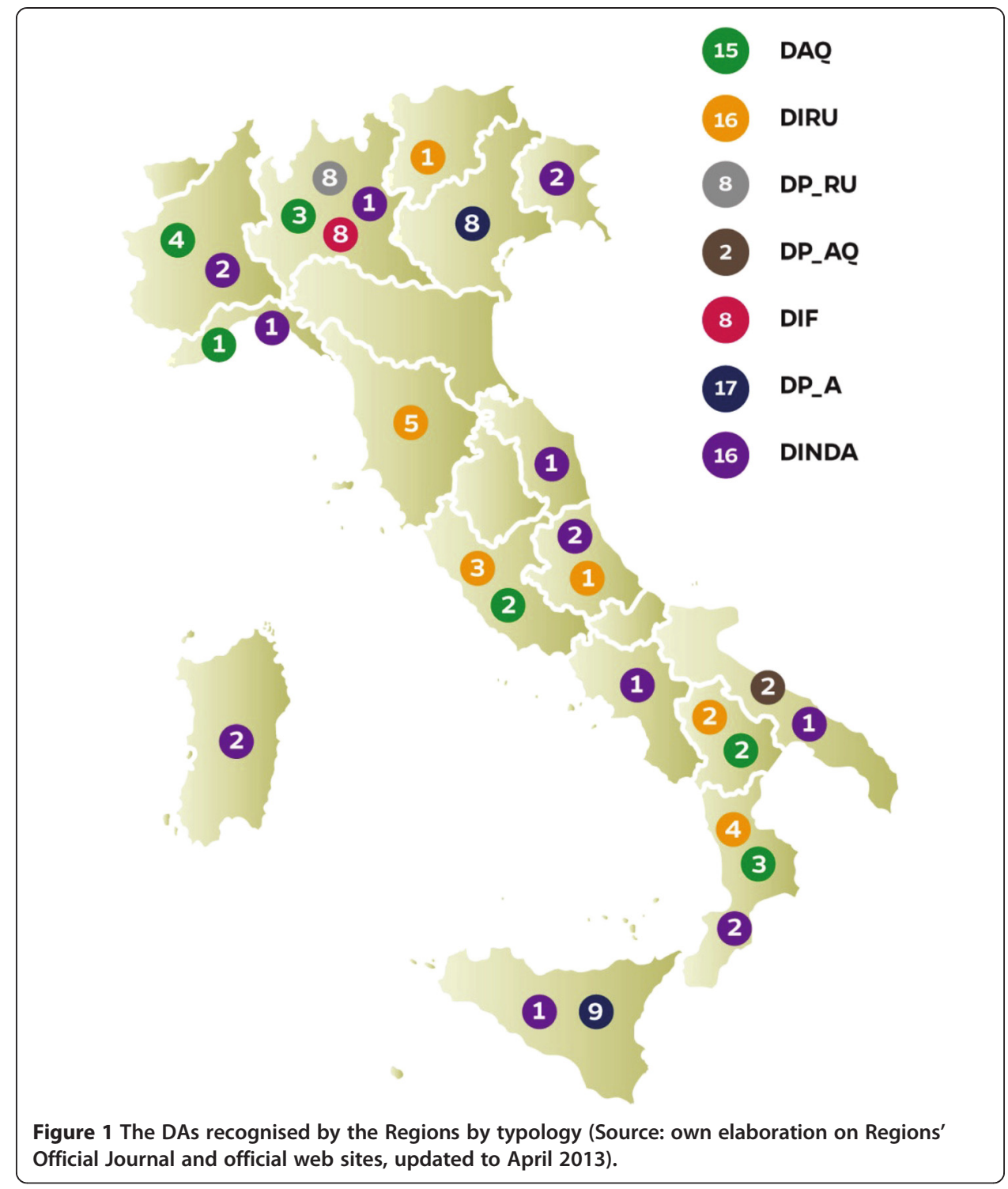

The political component, albeit often deemed external to the conceptual economic framework, in this kind of design is considered essential, because it is by law that life in the districts is regulated. So this component is considered in the sense of policy to be implemented on a local scale and is expressed through the norms for regulating what kind of DA project may be accepted and how they may be supported by public finance. From this analysis derived our methodological approach and the 'methodological' common definition of DAs, which is the milestone for some general reflections about the possible future use of DAs.

In the second phase, this more general concept of DAs is compared with a critical survey of the structural policies for 2014-2020, having regard to the extension of LEADER methodology to all European and Structural Investment (ESI) Funds ${ }^{\mathrm{k}}$, as well as to the increased attention paid by rural development policy to cooperation among farms, including in the form of networks and clusters. 


\section{Results and discussion}

\section{Findings from desk research into the DAs}

- From the map to the rationalisation types of DAs created by the Regions

Under the legislation discussed above, over time sixteen Regions have recognised 82

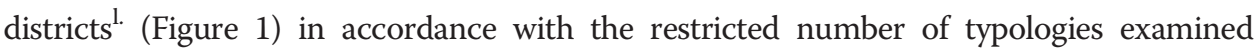
below (Table 2). The recognised DAs are either specialised, hence focused on a specific agricultural or agro-industrial production often with a designation of origin, or nonspecialised (Table 3). For reasons given above, there is not a univocal correspondence between typologies of districts and typology of specialisations. For example, some milk and dairy product districts have been recognised as quality agro-food districts, others as districts of the supply chain, others as production or industrial districts. More than half of the DAs (44) specialise in the following sectors: fruit and vegetables (9) plant nurseries (7), animal husbandry (6) wine (5), milk and dairy products (5), cereals, (3) fish (2), agroenergy (2) food biotechnology (2) cork (1) coffee (1) and confectionery (1).

The other non-specialist DAs (38) focus (23) on a basket of integrated products and services of the territory (Pecqueur 2001; Pacciani 2003; Belletti and Marescotti 2004) because of the awareness that the district -especially the rural district - determines an overall enhancement of the territory (Iacoponi 2002; Pacciani 2003). Typical products with designation of origin (Arfini et al. 2010) are usually at the core of that basket. This classification does not coincide with that (9) named multi-product, which includes those agro-industrial districts less concentrated on integrated action of territorial development, even if focused on several typical products. Among the non-specialised you see also some particular uses of DAs: reinforcing the rural economy of peri-urban areas and getting better governance for managing their relationship with the city (e.g. the rural district of Milan and the other three around the Milan metropolitan area); enhancing the environment and focusing on forest heritage in the Pistoia Mountains in Tuscany. Non-specialised DAs are mostly rural districts, signifying correct use of this tool.

Hitherto, the Regions have recognised a huge number of designations and types of DA for very different economic contexts and rural environments. Unfortunately it is not always understandable from regional laws or DA designations to which kind of juridical notion they refer. So a deeper analysis is needed for correctly re-organising the types of DAs created by the Regions, finding a first criterion to make the multifaceted universe of agricultural districts more homogeneous. The more logical choice seemed to combine the two criteria derived from legal bases: on the one hand, the basic subsequent notions of local productive systems (LPS) and production districts (DP) to which regional laws refer; on the other hand, the basic types of agricultural or industrial district. So all the district types named by the Regions (summarised in Table 4) are reduced to basic typologies on which we can now focus.

Table 2 DA typologies related to the main legal basis (Source: Toccaceli D. 2012:54)

\begin{tabular}{lll}
\hline & $\begin{array}{l}\text { Local Productive } \\
\text { System - (LPS) }\end{array}$ & $\begin{array}{l}\text { Productive } \\
\text { districts - (DP) }\end{array}$ \\
\hline $\begin{array}{l}\text { Rural and Quality Agro-Food districts (DRAQ) } \\
\text { Industrial Districts (DIND) }\end{array}$ & DIRU DAQ & DP_RU DP_AQ DIF \\
\hline
\end{tabular}


Table 3 DAs recognised by the Regions by main production sectors (Source: own elaboration)

\begin{tabular}{|c|c|c|c|c|c|c|c|c|c|}
\hline & & DAQ & DIRU & DP_RU & DP_AQ & DIF & DP_A & DINDA & Total \\
\hline \multirow[t]{5}{*}{ Non specialized } & Multi-product & & & & & & 1 & 8 & 9 \\
\hline & Basket products-territory & 6 & 11 & 4 & 2 & & & & 23 \\
\hline & Urban-rural & & 1 & 4 & & & & & 5 \\
\hline & Forestry rural & & 1 & & & & & & 1 \\
\hline & Subtotal & 6 & 13 & 8 & 2 & 0 & 1 & 8 & 38 \\
\hline \multirow[t]{14}{*}{ Specialized } & Agro-energy & & 1 & & & 1 & & & 2 \\
\hline & Food biotechnologies & & & & & & & 2 & 2 \\
\hline & Coffe & & & & & & & 1 & 1 \\
\hline & Cereals & 1 & & & & & 1 & 1 & 3 \\
\hline & Confectionery & & & & & & 1 & & 1 \\
\hline & Plant Nurseries & 2 & 2 & & & 2 & 1 & & 7 \\
\hline & Fish & & & & & & 2 & & 2 \\
\hline & Milk and milk dairy products & 1 & & & & 1 & 2 & 1 & 5 \\
\hline & Fruit and vegetables & 3 & & & & 1 & 4 & 1 & 9 \\
\hline & Cork & & & & & & & 1 & 1 \\
\hline & Wine & 2 & & & & & 2 & 1 & 5 \\
\hline & Animal husbandry & & & & & 3 & 3 & & 6 \\
\hline & Subtotal & 9 & 3 & 0 & 0 & 8 & 16 & 8 & 44 \\
\hline & Total & 15 & 16 & 8 & 2 & 8 & 17 & 16 & 82 \\
\hline
\end{tabular}

Moreover, it should also be noted how the methodological link between LEADER and rural districts (Belletti and Marescotti 2007) found expression in real life. Because LEADER-eligible areas have the same general characteristic as those where rural districts are recognisable, sometimes some LAGs planned to evolve into rural districts and did so. This happened in two ways, either achieving recognition from their Region (e.g. the LAGrural district Serre Calabresi or the LAG Golem in Lombardy which led to recognition of DIRU Franciacorta-Sebino-Valtrompia); or, where there were no regional laws, defining

Table 4 Regional criteria for identifying and recognising DAs (source: own elaboration in Toccaceli 2012)

\begin{tabular}{|c|c|c|c|c|}
\hline \multirow[t]{2}{*}{ Indicators } & \multicolumn{3}{|l|}{ LPS } & \multirow{2}{*}{$\begin{array}{l}\text { DP } \\
\text { All types }\end{array}$} \\
\hline & DINDA & DAQ & DIRU & \\
\hline \multirow[t]{2}{*}{$\begin{array}{l}\text { Spatial } \\
\text { (concentration) }\end{array}$} & $\begin{array}{l}\text { Statistical indicators } \\
\text { less restrictive than } \\
\text { those for Industrial } \\
\text { district }\end{array}$ & & $\begin{array}{l}\text { Homogeneous rural } \\
\text { identity of the territory }\end{array}$ & Statistical indicators \\
\hline & Territorial contiguity & Territorial contiguity & Territorial contiguity & $\begin{array}{l}\text { Wider areas also } \\
\text { without contiguity }\end{array}$ \\
\hline \multirow[t]{5}{*}{$\begin{array}{l}\text { Business } \\
\text { (specialization) }\end{array}$} & \multirow{4}{*}{$\begin{array}{l}\text { Specialised and } \\
\text { integrated supply } \\
\text { chains }\end{array}$} & $\begin{array}{l}\text { Quality of agro-food } \\
\text { production }\end{array}$ & & $\begin{array}{l}\text { Economic importance } \\
\text { of the sector }\end{array}$ \\
\hline & & $\begin{array}{l}\text { Integrated supply } \\
\text { chains }\end{array}$ & Multi-sector integration & $\begin{array}{l}\text { Integrated supply } \\
\text { chains }\end{array}$ \\
\hline & & Territorial integration & Territorial integration & \\
\hline & & Innovation & - & Innovation \\
\hline & Governance & Governance & Governance & Governance \\
\hline
\end{tabular}


themselves or their planning target as a "rural district". Examples of this are the LAG "L'altraromagna" which in 2007/13 developed a local action plan for "the rural district of biodiversity", or several LAGs in the Sardinia Regionm. Another example comes from the Marche Region where the LAG Colli Esini designed the Rural District Colli Esini as an innovative project to promote its territory. Reading their local action planning documents, the idea emerges that the DIRU are deemed able to boost the image and attractiveness of the area and re-create conditions of economic value creation in a more integrated and stronger way. In some other cases District and LAG paths are distinct but synergistically intertwined (e.g. the Quality Agro-food district of Castelli Romani and Monti Prenestini).

- The DAs' economic mechanisms shaped by the Regions

\section{The spatial and business dimensions}

Bearing in mind the evolutionary path along which the legal notion of DAs has evolved over the years, modifying its relation to the scientific concept, this analysis shows how the economic function varies for the different typologies.

The Regions have shaped these dimensions using a long list of criteria to identify and legally recognise the DAs (Table 4). We discuss the four essential types of DA identified, in chronological order and distinguishing the spatial indicators of proximity from the business indicators of businesses' specialisation and concentration.

The first definition of industrial district, later discarded, based on the spatial dimension of "local territorial area", hinged on the concept of local labour system based on commuting elaborated by Sforzi (1987). It was identifiable thanks to a set of statistical indicators signifying the concentration of enterprises, entrepreneurs and workers in a very specialised sector which was really important for a certain area.

Held to be too restrictive, after 1999, for the spatial identification of local production systems (LPS), and consequently for agro-industrial districts (DINDA), some discretional and qualitative criteria were added, in order to be able to include many more districts that did not correspond to some of the statistical requirements.

For the rural and agro-quality food districts (DRAQ), the Regions elaborated a rich array of criteria which strictly corresponded to the main points of their legal definition. First, they specified two differentiated requirements: for the rural districts (DIRU), a homogeneous rural identity of the territory as well as integration between agricultural and other local activities; for the quality agro-food districts (DAQ), the presence of quality or typical agro-food products with certified origin as well as interconnection among farms and agro-food enterprises. They also specified two common requirements: the integration of the district's enterprises with the territory, expressed by the production of typical goods, representative of the territory and a well-organised mechanism of governance requested by each Region. Again, there are some links between LEADER and DAs. For example, the Piedmont region has defined its requirements for rural districts as above, but said that they are basically similar to the LEADER programme and cover the same rural zones, so DAs are not recognised in that region to avoid ineffective overlapping. 
Like industrial districts, production districts (DP), to be recognised, must demonstrate by a set of statistical indicators their economic relevance and vertical integration of the supply chains. Also the capacity for innovation is required.

Without exception, all the Regions require evidence of governance requirements, that is, a governance process and an effective partnership agreement in place.

\section{Institutions, organisation and governance patterns (socioeconomic dimension)}

The Regions have taken different political approaches (not part of this analysis, as mentioned above) in dealing with the wide category of institutions which may be public, semi-public and private actors, also non-local, and their possible networks, which may be formal, semi-formal or informal. The Regions have produced a broad range of possibilities. To cite an example, Tuscany has a network approach, and its regulation is very confident about the local network's effectiveness, so there is little legislation about governance. Conversely, a greater group of Regions that have an implicit top-down approach have much more regulated and formalised partnership arrangements. This group includes those Regions that have shaped DAs as effectively implementing rural development policy, also conferring upon them funding.

Apart from this rough distinction, it is very hard to recognise any more detailed pattern by which to organise the district's bodies. More or less formalised, those bodies are conceived for working on two basic functions: governance at local level, to identify aims and draw up the project; and management, to implement the district project and strategy. Considering these basic functions only, we can distinguish (Table 5) either a single pattern for those Regions which envisage only one body (usually named District Committee) to carry out both functions for the district (in some cases the president of the district is the representative); or a dual pattern, when two distinct bodies are planned, one for each function. Under the 2006 Finance Law, some Regions have requested a Representative of the district to be identified, charged with interfacing with the public administration at various levels. In the dual pattern, this may be the person charged with management functions, in the single pattern, when it occurs, it may be the district committee or an addition to it. A different pattern is followed by Lombardy whose DAs are composed entirely of enterprises, so the DAs are organised just by a District Company. A legal form to constitute those bodies is established in some Regions with various more specific requirements.

The very articulated, differentiated and complex procedures for promoting, constituting and sometimes formalising the governance process and partnership-forming often require proof of the bottom-up character of this process, even when an implicit desire for control is easily detected. This demonstrates a shared acknowledgement of the importance of trusting in involvement of local and private actors for a successful district.

\section{The policy implementation dimension}

Almost paradoxically, at least in relation to the conceptual framework, the Veneto and Sicilia Regions consider the development of the district project one of the most important requirements for recognising a district. For them, the district practically coincides with or is embedded in its project, as confirmed by the unique procedures for financing 
Table 5 DA governance patterns: the bodies and their functions - Own elaboration of regional laws in force

\begin{tabular}{|c|c|c|c|c|c|}
\hline Patterns & Regions & Governance functions & Management functions & Representation & Legal form \\
\hline \multirow[t]{8}{*}{ Dual } & Veneto (DP) & Every subject involved in the district (informal network) & Pact Representative & & Representation mandate \\
\hline & & Regional Board of Districts and meta-districts & - & & - \\
\hline & Sicilia (DP) & - & Pact Representative & & Individual form \\
\hline & & Regional Board of Districts & - & & - \\
\hline & Piemonte (DAQ) & District Desk & Company of District & & Company form or associative \\
\hline & Calabria (DRAQ) & District committee & Company of District & & Company form \\
\hline & Lazio (DRAQ) & District Committee & Company of District & & Joint-stock company also consortium \\
\hline & A.P. of Trento (DIRU) & - Valley Community -Committee of participation & Agency & - & Not required \\
\hline \multirow[t]{5}{*}{ Single } & Friuli VG (DINDA) & ASDI & & & Consortium company \\
\hline & Abruzzo (DAQ) & Company of District & & & Capital company \\
\hline & Basilicata (DRAQ) & District Committee & & - & Not required \\
\hline & Liguria (DAQ) & District Committee & & District President & Not required \\
\hline & Puglia (DP) & District Committee & & District President & Not required \\
\hline Company & Lombardia (DP) & - & Company of District & & Company form \\
\hline Network & Toscana (DIRU) & Coordinator & - & - & Not required \\
\hline
\end{tabular}


districts established by Veneto, described below. It is just an example, but one that says something about the conception and the concrete expectations about this policy tool.

This brings us into the operational dimension, as the project (also called pact or plan or programme) always has clearly expressed rules, for achieving the real aim of mobilising local resources towards innovative actions along medium-term pathways. In fact "district project" invariably means a group of individual or collective projects, always private enterprises, sometimes public too, together coherent with the main objective of the strategy. Usually the project has to be 'ready to be implemented' so it has to include feasibility studies and, when specific finance is provided, an economic-financial plan. Some regional regulations require projects to be subscribed by all the participants in the district, to assure their commitment to working together, to investing and (where needed) to co-financing as agreed. In those cases the project becomes the object of a binding contract.

Even if the procedures for elaborating the project are different, its elements (Table 6) are always the same: a socio-economic analysis of the districtual area, the chosen objectives and the strategy for achieving them, the partnership composition, a plan of action and the financial plan. Monitoring, always prescribed, is not much stressed. The project is evaluated and, if approved, financed by the Region.

So the project has three main features. It is always integrated, either in a vertical way in the case of districts mainly focused on products and supply chain, or in a horizontal way in the case of districts mainly focused on local development. It is strategic, so in the specified time of three years (the same in all Regions) it focuses only on the chosen strategic goal. It is programmatic in all those Regions which finance, directly or not, the districts' projects. In this case the districts are a reference point for regional programming action. Finally, the project has usually (but not always) bottom-up promotion, again indicating that generally the Regions recognise that a good project - and its chance of success - requires good dialogue among the actors. As a matter of fact, a number of Regions support the preparatory actions for communicating the aims of the district and involving most of the actors.

It is observed that the more or less implicit desire for control by the Regions over the district's actions is strictly related to the acknowledgement of a specific line of credit to the DA project. The case of Veneto is emblematic, which provides a specific three-year credit line, so that the DA's actions, realisations and financial reports are always under regional control.

For financing, too, it is very hard to identify any pattern (Table 7), as every Region has followed its own path regarding the procedures, juridical tools and the aspect to be supported.

Regarding financing of projects, there are three specific ways. One is to use negotiated planning tools. In other cases, a few Regions provide a specific line of credit within the regional budget, so that recognising the district, approving the project and granting funding may be contextual. Some other Regions reserve a share of the regional rural development plan for DAs.

Sometimes DA projects are included in regional planning as specific actions to implement one or more policies, in an integrated way and following multiple aims (e.g. rural development and environmental sustainability or enhancing firms' competitiveness and internationalisation and innovation processes). 
Table 6 A comparison between DA project elements and CLLD strategy elements - own elaboration

\begin{tabular}{|c|c|c|}
\hline Elements & DAs & CLLD (Reg. UE 1303/2013) \\
\hline \multirow[t]{2}{*}{ Analysis } & \multirow{2}{*}{$\begin{array}{l}\text { Ex-ante analysis of situation in district (with } \\
\text { help of SWOT analysis), socio-economic } \\
\text { situation and situation of main productive } \\
\text { sectors. }\end{array}$} & $\begin{array}{l}\text { (a) definition of area and population covered } \\
\text { by strategy; }\end{array}$ \\
\hline & & $\begin{array}{l}\text { (b) analysis of development needs and } \\
\text { potential of area, including an analysis } \\
\text { of strengths, weaknesses, opportunities } \\
\text { and threats; }\end{array}$ \\
\hline Strategy & $\begin{array}{l}\text { Definition of strategic objectives and targets. } \\
\text { Identification of main lines of action and } \\
\text { innovative actions. Indication of expected } \\
\text { results. }\end{array}$ & $\begin{array}{l}\text { (c) description of strategy and its objectives, } \\
\text { description of integrated and innovative } \\
\text { features of strategy and hierarchy of objectives, } \\
\text { including measurable targets for outputs or } \\
\text { results. In relation to results, targets may be } \\
\text { expressed in quantitative or qualitative terms. } \\
\text { The strategy shall be consistent with relevant } \\
\text { programmes of all ESI Funds concerned; }\end{array}$ \\
\hline Partnership & $\begin{array}{l}\text { Identification of public and private } \\
\text { stakeholders involved in project and indication } \\
\text { of mode of their involvement (usually required } \\
\text { to form a legal entity) }\end{array}$ & $\begin{array}{l}\text { (d) description of community involvement } \\
\text { process in development of strategy; }\end{array}$ \\
\hline \multirow[t]{2}{*}{ Planning } & $\begin{array}{l}\text { Presentation of single initiatives proposed, } \\
\text { sometimes including initiatives of public nature, } \\
\text { such as infrastructure of service to the district. }\end{array}$ & \multirow[t]{2}{*}{$\begin{array}{l}\text { (e) action plan demonstrating how objectives } \\
\text { are translated into actions; }\end{array}$} \\
\hline & $\begin{array}{l}\text { Indication of feasibility of initiatives and reali } \\
\text { sation times }\end{array}$ & \\
\hline Monitoring & Usually an annual report is requested. & $\begin{array}{l}\text { (f) description of management and monitoring } \\
\text { arrangements of strategy, demonstrating } \\
\text { capacity of local action group to implement } \\
\text { strategy and description of specific } \\
\text { arrangements for evaluation; }\end{array}$ \\
\hline Financial plan & $\begin{array}{l}\text { Development of financial plan detailing share } \\
\text { of contribution required from Region (where it } \\
\text { provides direct financing with regional resources) } \\
\text { and financial commitments made by each } \\
\text { participant and sources of public (EU, national } \\
\text { and regional) funding identified. }\end{array}$ & $\begin{array}{l}\text { (g) financial plan for strategy, including } \\
\text { planned allocation from each ESI Fund } \\
\text { concerned. }\end{array}$ \\
\hline
\end{tabular}

Table 7 Regional choices regarding financing DA projects - own elaboration based on regional laws in force

\begin{tabular}{llll}
\hline $\begin{array}{l}\text { Regional support only to } \\
\text { preparatory actions }\end{array}$ & $\begin{array}{l}\text { Negotiated } \\
\text { planning tools }\end{array}$ & $\begin{array}{l}\text { Financial line of the } \\
\text { regional budget }\end{array}$ & $\begin{array}{l}\text { Reserved share } \\
\text { of regional RDP }\end{array}$ \\
\hline Friuli V.G. & $\begin{array}{l}\text { Friuli V.G. } \\
\text { Veneto }\end{array}$ & Puglia \\
Lombardia & Puglia & & \\
Sicilia & A.P. Trento & Sicilia & \\
Lazio & P.A. Trento & Lazio & Abruzzo \\
Liguria & Abruzzo & & \\
Piemonte & Casionilicata \\
Basilicata & Casilicata & & \\
Toscana & Toscana & & \\
\hline
\end{tabular}


In all events, most Regions consider coordinated use of existing policies to implement the district project as the culmination of the district's path.

\section{The methodological approach to DAs}

Having completed the desk research, we can summarise the main findings and attempt to identify some logical consequences.

It may be generally stated that the Regions see DAs as supporting the competitiveness of agricultural enterprises and their innovation processes, strengthening the agricultural and agro-food supply chains and opening them to international markets, developing rural areas, protecting the environment and managing the relationship between city and countryside in peri-urban areas.

More specifically it may be observed that those aims are pursued in a differentiated way, so that there is a range of variation in the understanding of DAs' functions and applications. These range from the totally horizontal, conceived for aims of rural development and environmental sustainability, to the totally vertical focused almost exclusively on the competitiveness of farms and firms in the agricultural and agro-food supply chains and their innovation processes. It is self-evident that this presumed assignation makes more political than scientific sense. This misconception may have thus influenced the correct use of this policy tool.

We have reduced the array of DA designations made by the Regions to four categories derived from the main legal basis, in order to obtain an initial criterion to proceed with our analysis. Although useful, this criterion was not enough to read such a complex phenomenon, e.g. for univocally linking any typology to a function or a way of financing DAs.

Without exception, the Regions have established such a set of criteria as to allow the development of the economic process, selecting districts with requirements of proximity, concentration and specialisation, coherently differentiating them in function of their main orientation towards the horizontal or the vertical dimension.

We note a variety of approaches to network, ranging from the informal involvement of multiple local actors. At the other extreme, the district coincides with the local partnership agreement, despite the fact that the operational solutions adopted for recognising and making operative the network are generally very complex and time-consuming. This variety of approaches was our primary reason for attempting a methodological approach for finding a common basic definition of Italian DAs.

This impression is reinforced by the fact that a prerequisite for the recognition of DAs and the basis of their successful functioning in all regional laws is the implementation of broad governance processes, mostly at local level.

To concretise the strategy, the highest aim of the DAs is developing and implementing a medium-term project that is strategic and integrated. In most cases, it is also programmatic, in the sense that, in several Regions, DA projects become part of the process of regional planning policy, so they are also considered as a source of input information for the purposes of policy planning, management and land use planning.

Finally, we note that all the Regions introduced monitoring of the application of their own laws, although specific indicators of effectiveness are almost never mentioned. As a result no data - no comparable data - are available to enable objective analysis and deduction. 
This homogeneous method adopted by the Regions, despite differences and changes of political vision and leadership, was possible because, as has been observed (Toccaceli 2012), the methodological approach defined by the law on industrial districts has remained at the heart of all subsequent national legislation on DAs. Considering the subsequent assimilation of all kinds of district, it has been pointed out that the government has implicitly followed a methodological framework which remained constant and neutral in regard to various economic sectors of application and economic objectives, for which districts were prepared and used over time.

As a consequence, a methodological definition (see Figure 2) is proposed that qualifies DAs as a method of intervention at local level, based on a multi-level governance dynamic (Commission of the European Communities 2001; Committee of the Regions 2009). This comprises the local partnership - established among districtual firms and private and public local stakeholders and operating by a participatory method - which formulates a strategy and develops innovative projects for enhancing the districtual productive system. There is also a district representative, to dialogue with the Public Administration at various levels, even if informally identified among the local actors of the district. Through a specific juridical tool (in the form of a contract, e.g. the district pact) the projects are included in higher-level programming tools, in application of the principles of vertical and horizontal subsidiarity, so they are financed with public and private sources and implemented. This definition focuses on the complex system of relationships linking the different actors at local and also at higher level, where the privileged interlocutor is the Region, through which policies are passing as a result of the national devolution process and application of the principle of horizontal and vertical subsidiarity.

The district thus defined, because of the principles that animate it, is consistent with post-2013 rural development policy, both for its participatory approach and for the

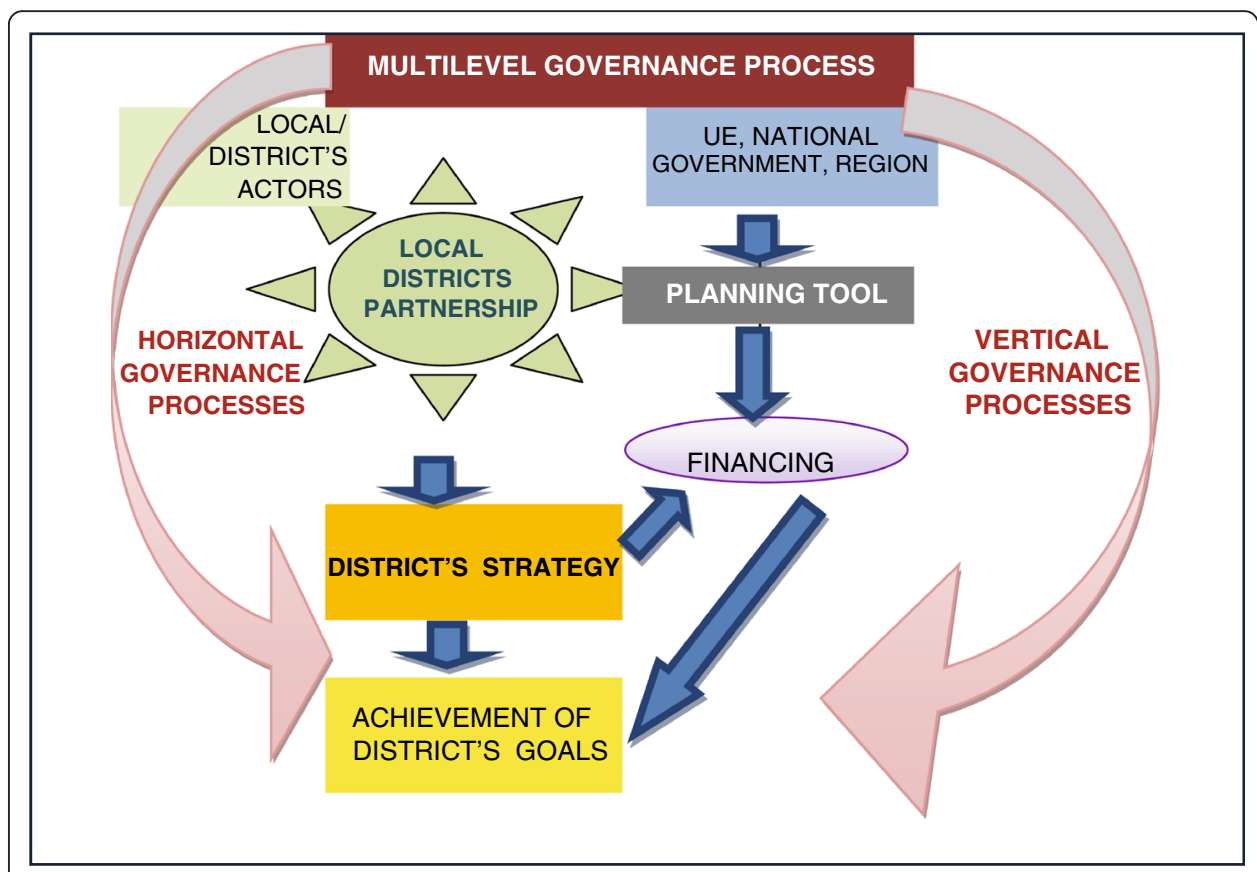

Figure 2 The general methodological scheme of DAs (Source: Toccaceli D. 2012:46). 
local scale of intervention which is significant to implement European Structural and Investment Funds, more so than in the past.

The DAs in the perspective of the 2020 European goals for agriculture and rural development

At the time of Agenda 2000, rural and quality agro-food districts were established within the context of a significant set of tools to modernise and strengthen Italian agriculture, in the face of new scenarios of increased exposure of firms to global competition. Two programming cycles later, Italian agriculture and rural territories still need to be strengthened, including through new organisational solutions (Canali 2013:79) to enhance their competitiveness.

More in general, in the period of Europe 2020 strategy, old and new challenges have to be faced by means of the CAP and the rural policy, as well as the other ESI Funds (De Castro 2010; De Castro et al. 2011; De Filippis 2012). These include food security and food quality concerns generating great demands on food systems, environmental concerns linked to the loss of biodiversity, landscape deterioration and the demand for renewable sources of energy.

The EU has reinforced its strategic approach, linking all ESI funds under common provisions and a set of guiding principles, the Common Strategic Framework (CSF), as well as establishing eleven Thematic Objectives on which ESI Funds support should be concentrated. The strategy is based on (among others) the principle of multilevel governance and partnership. So, in utilising ESI Funds, every Member State is requested to prepare a Partnership Agreement reached with the Commission and a broad national partnership.

In the light of this new orientation of European policies and considering the comprehensive methodological definition of DAs, we can attempt to give a detailed answer to our main research question. We asked ourselves whether and how DAs may be still useful in new programming policies, with reference to structural policies, more in particular to rural development policy and with special attention to the relation between DAs and LEADER method and programmes.

More so than in the past, the local level is key in implementing policy measures. Indeed a specific chapter of the CSF Regulation is dedicated to community-led local development ${ }^{\mathrm{n}}$. (CLLD) which supports local strategies led by a Local Action Group (LAG) and thanks to multi-fund financing. The device established by the EU is modelled on LEADER methodology so, analysing point by point the main features of CLLD, it is not surprising to find great similarity between CLLD methodology and DA principles. The new possibility of carrying out integrated and multi-sectorial area-based development strategies and of supporting them by multi-fund resources is the most significant similarity and a new opportunity for DAs too (especially for Rural Districts). In fact this new tool becomes more important given the different types of rural territory, especially considering the wide-ranging 'ruralities' from remote to peri-urban rural areas. In the new context, there should not be a dichotomy between urban and rural, rather a more proactive relationship. Starting anew from their own endogenous potential, rural areas are called on to develop "smart specialisation" based both on their territorial capital and local actors' capability to act together to put in place successful strategies. 
Focussing on rural development policy, the European agricultural fund for rural development (EAFRD) contributes to achieving specific objectives ${ }^{\mathrm{o}}$ (agriculture competitiveness, environment and rural territories development) following detailed priorities ${ }^{\mathrm{p}}$. in accordance with the CAP framework. So this Fund has established precise measures which may be considered useful for DAs, or which may be more effectively implemented where there is a "district atmosphere" and thanks to DAs. Within the EAFRD framework, strong attention is paid to the role played by co-operation ${ }^{\mathrm{q}}$, so the related measure, reinforced and enlarged in comparison with the past and intended to stimulate innovation, is very complex and multi-purpose. In fact, the concept of innovation is very broad and the possible forms of co-operation are highly articulated with respect to the possible subjects involved, in order to respond to all the strategic objectives of the fund: environmental, competitive and territorial balance (Table 8). For this paper's purpose, we note that co-operation can involve different actors from the food chain, agriculture or forestry sectors, as well as producer groups, cooperatives and interbranch organisations. Co-operation may also be intended to "create clusters or networks. ", even if they have to be "newly formed" and "commencing an activity that is new to them", in order to pursue the aim of innovation.

Support may also be given to the "implementation, in particular by groups of public and private partners of local development strategies"s. adding it to the CLLD and limiting it to EAFRD support. So it seems that many types of DA and DA project might be covered by this measure, if Regional planning allows and provides for this.

Furthermore, a broad typology of cost is eligible and "where a business plan or an environmental plan or a forest management plan or equivalent or a development strategy is implemented, Member States may grant the aid either as a global amount covering the costs of co-operation and the costs of the projects implemented or cover only the costs of the co-operation and use funds from other measures or other Union Funds for project implementation"t, obviously avoiding any over-compensation. It should be underlined that many different contexts and purposes can be adapted into the bundle of this detailed and flexible measure. Also, DAs might strengthen their partnership or renew their project for innovating, whether they are quality agro-food, or rural, or aiming to manage relationships between rural and urban areas, or focused only on a single product or food supply chain, considering that these tools depend on the good functioning of multi-level governance. Generally speaking, it might be more effective in those cases where governance pathways are already set out.

Finally, the multiple contact points between DAs and LEADER suggest two different points.

On one hand, "district thinking" may suggest some indications about LEADER Programmes newly financed by EAFRD. The European Court of Auditors (2010), among other more specific observations, pointed out that local action groups' (LAGs) actions were not well focused on local strategic objectives, and that the added value due to the LEADER approach was not seen to be achieved. Even if those recommendations have been taken into account by the European Commission and Member States to formulate better rules to ensure those gaps will be filled, in practice, "district thinking" may be useful in better concentrating local strategies, and resources as well, on the most active value chains that may activate interactions among enterprises of all sectors or belonging to a same value chain. 
Table 8 The 'bundle' measure of co-operation in EAFRD, Reg. (UE) 1305/2013 Article 35 (2), referred to EAFRD general objectives Article 4 - (source: Toccaceli 2012:101)

Eafrd objectives article 4
(a) fostering the competitiveness of
agriculture

(b) ensuring the sustainable management of natural resources, and climate action
Co-operation actions supported By Eafrd Article 35

(a) pilot projects;

(b) the development of new products, practices, processes and technologies in the agriculture, food and forestry sectors;

(c) co-operation among small operators in organising joint work processes and sharing facilities and resources and for the development and/or marketing of tourism services relating to rural tourism;

(d) horizontal and vertical co-operation among supply chain actors for the establishment and the development of short supply chains and local markets;

(e) promotion activities in a local context relating to the development of short supply chains and local markets;

(f) joint action undertaken with a view to mitigating or adapting to climate change;

(g) joint approaches to environmental projects and ongoing environmental practices, including efficient water management, the use of renewable energy and the preservation of agricultural landscapes;

(h) horizontal and vertical co-operation among supply chain actors in the sustainable provision of biomass for use in food and energy production and industrial processes;

(j) drawing up of forest management plans or equivalent instruments;

(c) achieving a balanced territorial development of rural economies and communities including the creation and maintenance of employment (i) implementation, in particular by groups of public and private partners other than those defined in point (b) of Article 32(2) of Regulation (EU) No 1303/2013, of local development strategies other than those defined in Article 2(19) of Regulation (EU) 1303/2013 addressing one or more of the Union priorities for rural development;

(k) diversification of farming activities into activities concerning health care, social integration, community-supported agriculture and education about the environment and food.

On the other hand, "LEADER thinking" may help to point out some strong and weak points in DAs. Our research shows that DAs shaped by Regions are always conceived as competitive development tools to enhance agricultural and agro-food assets and to reinforce the local rural system, Thanks to our new-found methodological approach, we can say that DAs, by design, have proved to be:

- A flexible method. Based on different and changing political inspirations, Regions have adjusted the district tool to fit many different cases, given the high degree of autonomy that now exists following extension of the LEADER method to ESI Funds.

- A homogeneous method. Though each Region was following its own purposes, together they have inspired and contributed to formulating a methodological pattern with common and homogeneous features.

- A stable structure for organising the local economy. The fact that all Regions ask DAs to make updatable three-year projects indicates that DAs are designed as a stable structure designed, in many cases, to become a constant reference point in the programming of regional policies. It is true that the complex mechanisms required to set up DAs may be so tiresome as to envisage the possibility of numerous failures or 
dropouts. However, the very amount of time spent in setting up DAs may be considered a strong point if it means practising dialogue among local stakeholders. So DAs can be regarded as a flexible device for policy delivery.

Conversely, the most evident weak point of DAs is that, more than ten years after the Law of Orientation, it is still impossible to know more about the DA phenomenon because there is no constantly updated information about regional choices, regional legal sources or DAs actually operative, nor is there a regional system for monitoring DA performance.

In comparison with the LEADER method one may evaluate DAs' critical points, looking at three "genetic" weaknesses:

- DAs do not form a network among themselves. So, within their own regulation, they have neither territorial cooperation nor a place to exchange their experiences.

- Only some DAs can rely on a certain perspective of financial support, as successful implementation of medium term planning is requested for this.

- They lack a monitoring system by third parties. Every Region has made monitoring compulsory by law. But - especially in cases where the law already provides for a regional non-financial line dedicated to the DA - there are no actual evaluations of effectiveness of the method, nor even homogeneous surveys able to present more generalised elements of assessment.

So, even if still an expanding phenomenon, the DA method lacks an evaluation system, such as that of LEADER, to permit learning from mistakes and the updating itself, rather than fostering ineffective consumerism of policy tools.

\section{Conclusions}

This article aimed to create the conditions for carrying out research on national scale into DAs, starting from an unclear political, juridical and economic context. Thanks to the "reconstructive reading" of the legal bases as well as of the conceptual economic framework, and to desk research into DAs shaped by regional laws, we analysed how the basic components of the district conceptual framework were elaborated by the different Regions in such a way as to ensure the conditions for displaying the potential of the 'district process'. Even if we could not identify a specific pattern because of the different political approaches developed over time, a methodological approach was found that allowed us to outline the DAs' common points and their economic mechanisms and to collect them into a general definition.

On this basis, it was possible to develop a general reflection on the possible future use and utility of DAs, integrating them into the coming programming period. At the same time, some of these reflections on DAs may offer suggestions for other Countries where the same regulation is in force. So, the chances for the coming years are linked to different scenarios, whether the main purpose is either reinforcing weak and marginal rural systems or enhancing competitiveness of strategic supply chains. Two ways are possible: 
- assimilating DAs and LAGs indicated for developing and implementing multi-fund local strategies (CLLD). This depends on the success of DAs, i.e. whether DAs emerge as an example of stable organisation of the local economy and good governance or not.

- including DAs in the 'bundle' of the co-operation measure : constituting new clusters and networks for the wide range of aims covered by the law; referring to supported implementation by groups of public and private partners of local development strategies.

These new opportunities would allow Regions to overcome some of the weaknesses highlighted and have systems in place for standardised, constant monitoring and evaluating in the medium term. Regions could also make use of the results of evaluation and monitoring, which would be available for the first time; to improve DA methods, just as the LEADER method was improved over time.

In conclusion we remark that this paper refers to the findings of the first survey of DAs, developed on national scale. Although it contributes towards classifying some early points, many questions remain open for further research.

\section{Endnotes}

a'Region' includes also the autonomous Provinces of Trento and Bolzano, which can legislate just like a Region.

${ }^{\mathrm{b}}$ Legislative decree 18 May 2001 n. 228 " Orientation and modernization of the agricultural sector in accordance with Article 7 of Law 57 of March 5, 2001». Published on G.U. n.137 of 15/6/2001 Ord. Suppl. n.149. Art.13 «Rural and quality agro-food districts». It is also named 'Orientation Law' in analogy with the French 'Loi d'orientation agricole'.

"In the following "DA" is used for generically indicating each type of district in agriculture.

${ }^{\mathrm{d}}$ A not exhaustive list of studies on regional case studies includes: Pacciani (2003), Regione and Agenzia Regionale Servizi Sviluppo Agricolo (1999); Saraceno (1992); Casati et al. (1999); Pacciani (2002b); Pacciani (2003); Belletti and Marescotti (2004); Conti (2005); Aimone (2006); Toccaceli (2006); CNEL (2007); Fazio and Ricciardi (2008); Gulisano et al. (2008); Hoffmann (2008); Marangon (2008a); Marangon 2008b); Baldi and Casati (2009); Belletti and Marescotti (2010); Contò et al. (2010); Petrovich and Manzoni (2010); Caré et al. (2010); Contò and La Sala (2011); Garofoli (2011); Maizza (2010); Montresor et al. (2011); Tarangioli (2008); Tarangioli (2011); Spampinato and Timpanaro (2012).

${ }^{\mathrm{e}}$ Just defined in Article 5 of the Treaty on European Union, both were issued since 1992 in a declaration of Edinburgh European Council-

${ }^{\mathrm{f}} \mathrm{LEADER}$ is the acronym for: Liason Entre Actions de Développement de l'Économie Rurale, that is "Links between actions for the development of the rural economy".

${ }^{\mathrm{g}}$ Three EU schemes promote and protect names of quality agricultural products and foodstuffs: Protected Designation of Origin - PDO: covers agricultural products and foodstuffs which are produced, processed and prepared in a given geographical area using recognised know-how. Protected Geographical Indication - PGI: covers agricultural products and 
foodstuffs closely linked to the geographical area. At least one of the stages of production, processing or preparation takes place in the area. Traditional Speciality Guaranteed - TSG: highlights traditional character, either in the composition or means of production.

${ }^{\mathrm{h}}$ Towards the end of the ' 80 s the contributions (1987 and 1989) where Becattini systematizes the studies conducted on the industrial district of Prato and formulate the paradigm of the industrial district were published. At that time, some studies were carrying out on the contribution of agriculture to the determination of the pre-conditions for the development of an industrial district (Cecchi 1988; Cianferoni 1990; Cecchi et al. 1991).

${ }^{\mathrm{i}}$ Here and below the symbol “*” indicates our translation from italian.

${ }^{\mathrm{j}}$ See note b.

k'ESI (European Structural and Investment) Funds' are the European Regional Development Fund (ERDF), the European Social Fund (ESF), the Cohesion Fund, the European Agricultural Fund for Rural Development (EAFRD) and the European Maritime and Fisheries Fund (EMFF), which operate under a common framework and work together in a coordinated way according to common provision established by Reg. (EU) 1303/2013.

${ }^{\mathrm{l}}$ Updated to April 2013.

${ }^{m}$ E.g. The LAG "Rural district Barbagia-Mandrolisai-gennargentu-Supramonte" titled its local development plan "toward the rural district" and the LAG "Shardana Lands" titled "Path toward a sustainable rural district and for quality of life".

${ }^{\mathrm{n}}$ Reg. (EU) 1303/2013 Article 2(19).

${ }^{\circ}$ Reg. (UE) n. 1305/2013 Article 4.

${ }^{\mathrm{p} R e g . ~(U E) ~ n . ~ 1305 / 2013 ~ A r t i c l e ~} 5$

${ }^{\mathrm{q}}$ Reg. (UE) 1305/2013, Article 35.

${ }^{\mathrm{r}}$ Reg. (UE) n. 1305/2013, Article 2(1,q) «"cluster" means a grouping of independent undertakings, including start-ups, small, medium and large undertakings as well as advisory bodies and/or research organisations - designed to stimulate economic/ innovative activity by promoting intensive interactions, the sharing of facilities and the exchange of knowledge and expertise, as well as contributing effectively to knowledge transfer, networking and information dissemination among the undertakings in the cluster».

${ }^{s}$ Reg. (UE) n. 1305/2013, Article 35, (2,i).

${ }^{t}$ Reg. (UE) n. 1305/2013, Article 35, (6).

\begin{abstract}
Abbreviations
CAP: Common Agricultural Policy; CLLD: Community-Led Local Development; CSF: Common Strategic Framework; DA: District in Agriculture; DAQ: Quality Agro-Food District; DIF: Supply Chain District; DIND: Industrial District; DINDA: Agro-Industrial District; DIRU: Rural District; DP: Production District; DP_AQ: Quality Agro-Food Production District; DP_RU: Rural Production District; DRAQ: Rural and Quality Agro-Food Districts; EAFRD: European Agricultural Fund for Rural Development; ESI Funds: European Structural and Investment Funds; LAG: Local Action Group; LEADER: Links between Actions for the Development of the Rural Economy; MID: MARSHALLIAN INDUSTRIAL DISTRICT.
\end{abstract}

Competing interests

The author declares that she has no competing interests.

Author information

Dr. Daniela Toccaceli Ph.D. in Economics and territory, Post-Doc Fellow Department of Science for Economics and Business, University of Florence Via delle Pandette, 9 I-50127 Florence daniela.toccaceli@unifi.it. 
Received: 15 May 2014 Accepted: 19 November 2014

Published online: 21 January 2015

\section{References}

Adornato F (Ed) (2005) Sviluppo locale e contrattazione programmata Franco Angeli Milano

Aimone S., (Ed) (2006) Programmazione integrata e sviluppo rurale del Piemonte in: Quaderni di ricerca Istituto di Ricerche Economico e Sociali del Piemonte (IRES),Torino

Albisinni F (2010) Distretti e sviluppo rurale: elementi per una lettura delle regole di diritto, in: Agriregionieuropa, Anno 6n.20, pp.21-25 ISSN: 1828-5880

Albisinni F (2011a) Distretti e contratti di programma in agricoltura in Costato L. Germanò A. Rook Basile E. (Eds) Trattato di diritto agrario, Volume Primo:409-461 UTET, Torino

Albisinni F (2011b) Prodotti agro-alimentari e distretti in agricoltura In: Goldoni M, Sirsi E. (eds) II ruolo del diritto nella valorizzazione e nella promozione dei prodotti agro-alimentari: Giuffrè Milano pp103-148 ISBN: 88-14-17236-6

Angeli L (2000) L'atmosfera di Artimino e noi economisti agrari. La Questione Agraria n.3:111-121 ISSN: 1593-8441

Arfini F, Belletti G, Marescotti A (2010) Prodotti Tipici e Denominazioni Geografiche: Strumenti di Tutela e di Valorizzazione. Quaderni, Gruppo 2013, Roma

Baldi L., Casati D (2009) Un distretto della quarta gamma? II comparto che vende tempo libero, in: Agriregionieuropa, Anno5, n. 16, pp. 50-52, ISSN: 1828-5880

Becattini G (1987) Mercato e Forze Locali: il Distretto Industriale. II Mulino, Bologna, ISBN: 88-15-01420-9

Becattini G (1989) Riflessioni sul distretto industriale marshalliano come concetto socio-economico. Stato e mercato $25: 111-128$

Becattini G (2000) "Distrettualità" fra industria e agricoltura in La Questione Agraria n.2, pp: 11-24 ISSN: 1593-8441

Becattini G (2001) Distretti e ruralità: sfide al riduzionismo economico. Una replica in: La Questione Agraria n.1pp. 119-127. Franco Angeli, Milano, ISSN: 1593-8441

Becattini G, Bellandi M, Lisa DP (eds) (2009) A Handbook of Industrial Districts. Edward Elgar, Cheltenham, UK - Northampton, MA, USA, ISBN: 978-1-84720-267-3

Bellandi M (1987) La formulazione originaria in Becattini G., Mercato e forze locali: il distretto industriale: Il Mulino, Bologna

Belletti G, Marescotti A (2004) II Distretto Rurale: Metafora Organizzativa e Strumento di Governance. In: Hoffmann A (ed) Esperienze di Programmazione Dello Sviluppo Locale: il Caso del Parco dei Nebrodi. Franco Angeli, Milano

Belletti G, Marescotti A (2007) II Distretto Come Strumento di Governance per lo Sviluppo Rurale. In: Rete Leader, Leader e distretti rurali: sinergie e complementarietà. Biemmegraf, Macerata

Belletti G., Marescotti A (2010), II distretto rurale, In Pacciani A., Toccaceli D. (a cura di) Le frontiere dello sviluppo rurale. L'economia grossetana tra filiere e territorio, Franco Angeli, Milano, ISBN: 978-88-568-3268-6

Borràs S, Tsagdis D (2008) Cluster Policies in Europe. Edward Elgar, Cheltenam, Uk - Northampton, MA, USA, ISBN: 978-1-84542-758-0

Canali G (2013) L'OCM Unica e le Misure di Mercato. In: De Filippis F (ed) La Nuova PAC 2014-2020. Un'analisi Delle Proposte Della Commissione. Quaderno, Gruppo 2013, Roma

Caré V, Reda E, D'Angelillo E (2010) L'esperienza dei distretti rurali ed agroalimentari in Calabria. Evoluzione normativa ed iniziative proposte per un nuovo modello di governance e di sviluppo delle aree rurali. Rete Rurale Nazionale, Roma

Casati D (1988) Come cambia l'agricoltura nel sistema agro-industriale in Strategie e adattamento nel sistema agro-industriale INEA, Roma

Casati D, Banterle A, Baldi L (1999) II distretto agro-industriale del riso. Franco Angeli, Milano

Cecchi C (1988) distretto industriale: I'agricoltura dalla complementarità alla dissociazione. La questione agraria n.32, pp 91-123, Franco Angeli, Milano, ISSN: 1593-8441

Cecchi C. (1992) Per una definizione di distretto agricolo e distretto agroindustriale La Questione Agraria, n. 46, pp 81-107, Franco Angeli, Milano, ISSN: 1593-8441

Cecchi C (2000) "E se facessimo tanti bei campi da golf?": ovvero Becattini e la campagna La Questione Agraria, n.3, pp 123-132, Franco Angeli, Milano, ISSN: 1593-8441

Cecchi C, Cianferoni R, Pacciani A (1991) Economia e politica dell'agricoltura e dell'ambiente. CEDAM, Padova. ISBN 9788813173692

Cianferoni R (1990) L'agricoltura e l'ambiente nel distretto industriale di Prato. Accademia dei Georgofili, Firenze

Cnel (1999) I protagonisti e le esperienze locali di programmazione negoziata. CNEL, Roma

CNEL (2007) Distretti rurali ed aroalimentari di di qualità: il manifesto di Matera alla luce delle nuove politiche di sviluppo rurale. Osservazioni e proposte Assemblea CNEL del 20 Marzo, CNEL, Roma

Collignon P (2014) Le Syndicate intercommunal pour la promotion du canton de Clerveux "SYCLER" au service du développementglobal d'un territoire rural In: Pacciani A., Toccaceli D. (Eds) Percorsi di governance per la valorizzazione delle aree rurali nella prospettiva di riforma delle politiche europee, pp61-65 I Georgofili Quaderni 2013-II Società Editrice Fiornetina, Firenze ISBN: 978-88-6032-294-4

Commission of the European Communities (1988) The future of rural society, COM(88/501) Bruxelles: Bullettin of the European communities, Supplement 4/88

Commission of the European Communities (2001), European governance - A white paper COM(2001) 428 def., Bruxelles: Official Journal of the European Communities, C287/1, October, 10

Committee of the Regions (2009) The Committee of the Regions'White Paper on Multilevel Governance Own-Initiative Opinion, Bruxelles: 80th plenary session, 17 and 18 June

Conti L. (2005) Le politiche distrettuali della Regione Piemonte in: Agriregionieuropa Anno1, n. 2, pp. 39-41, ISSN: $1828-5880$

Contò F, La Sala P (2011) Approccio Territoriale e Sviluppo Locale. II Programma di Sviluppo del Distretto Agroalimentare di Qualità del Metaponto. Franco Angeli, Milano 
Contò F, La Sala P, Papapietro P (2010) Identità, Qualità e Competitività dell'area del Pollino: un Caso di Filiera "Atipica" Agro-Territoriale. Atti della XXXI Conferenza scientifica annuale AISRE, Aosta

Corò G, Grandinetti R (1999) Strategie di delocalizzazione e processi evolutivi nei distretti industriali italiani. L'industria AnnoXX 4:897-924

Courlet C., Pecqueur B (1992) Les systèmes industriels localisés en France: un nouveau modèle de développement In: Benko G., Liepitz A. (éds), Les régions qui gagnent. Districts et résaux: les nouveaux paradigmes dela géographie économique, PUF, Paris, pp.81-102

De Benedictis M (2000) Economia agraria e distrettualità in La Questione Agraria n.2, Franco Angeli, Milano, ISSN: 1593-8441 pp. 25-34

De Castro P (2010) L'agricoltura Europea e le Nuove Sfide Globali. Donzelli Editore, Roma

De Castro P., La Via G., Adinolfi F., Marangon F (2011) II processo di riforma della Politica Agricola Comunitaria Stato dell'arte e prospettive. In: International Agricultural Policy, n. 1, Edizioni L'informatore Agrario. Verona, ISSN: $1722-4365$.

De Filippis F (2000) Distrettualità e politica agraria in La Questione Agraria n.2, Franco Angeli, Milano, ISSN: 1593-8441

De Filippis F (Ed) (2012) La nuova PAC 2014-2020. Un'analisi delle proposte della Commissione Quaderni, Gruppo 2013, Roma

De Meo G., Nardone G (2002) Programmazione negoziata e sviluppo rurale in Basile E., Romano D., Sviluppo rurale: società, territorio, impresa, Franco Angeli, Milano

De Rita G., Bonomi A., (Eds)(1998) Manifesto per lo sviluppo locale Bollati Boringhieri, Torini

De Rosa M, de Vincenzo D (2002) Stato e Dinamica dei Sistemi Produttivi Territoriali nel Rapporto Locale/Globale. In: De Rosa M, de Vincenzo D (eds) Tra globalizzazione e localismo. Liguori, Napoli

European Union (2013) Official Journal of the European Union, L 347, Volume 56, 20 december 2013. ISSN: 1977-0677

European Commission's Directorates General AGRI, EMPL, MARE and REGIO (2013) Common Guidance on Communityled Local Development in European Structural and Investment Funds., http://ec.europa.eu/regional_ policy/informing/dialog/pdf/clld_guidance_2013_04_29.pdf (last access 15/04/2014)

European Court of Auditors (2010) Implementation of the Leader approach for Rural Development Luxembourg: Publication Office ISBN: 978-92-9207-883-6

Fabiani G (2000) Distretti o Sistemi Agricoli Locali? In: La Questione Agraria, vol 2. Franco Angeli, Milano, pp 33-41, ISSN: 1593-8441

Fanfani R, Montresor E (1998) Istituzioni e imprese nel percorso di sviluppo dei sistemi locali di produzione agroalimentare. La questione agraria n.69 pp.87-108 Franco Angeli, Milano ISSN: 1593-8441

Favia F (1992) L'Agricoltura nei sistemi produttivi territoriali. La questione agraria n.46 pp.109-136 Franco Angeli, Milano ISSN: 1593-8441

Favia F. (2000) Economia agraria e distrettualità: variazioni sul tema La Questione Agraria, n.3, pp.133-145 Franco Angeli, Milano, ISSN: 1593-8441

Fazio V, Ricciardi A (eds) (2008) II distretto della pesca di Mazara del Vallo. Una buona pratica di cooperazione tra aziende internazionali. Franco Angeli, Milano

Feser E., Isserman A (2009) The Rural Role in National Value Chains In: Regional Studies, 2009, vol. 43, issue 1, pp. 89-109, doi:10.1080/00343400801968429

Forleo M (2000) I Sistemi Agricoli Territoriali. In: CNEL, Secondo rapporto sull'agricoltura. L'agricoltura tra Locale e Globale. Distretti e Filiere vol N.23.Collana Documenti. CNEL, Roma, pp 295-324

Gallego Moreno F.J. (2014) La estructuraciòn y dinamizaciòn social para una mejor goberannza de las comunidades rurales: Caso de studio en Cuenca, Espana In: Pacciani A.r Toccaceli D. (Eds) Percorsi di governance per la valorizzazione delle aree rurali nella prospettiva di riforma delle politiche europee,pp29-49, I Georgofili Quaderni 2013-II Società Editrice Fiornetina, Firenze ISBN: 978-88-6032-294-4

Garofoli G (2011) La "Governance" Dello Sviluppo Locale Nelle Langhe, in: Seminario Nazionale su Politiche, Istituzioni e Sviluppo Rurale:Come Migliorare i Processi di Governance. Rete Rurale Nazionale, Roma

Gulisano G, Marcianò C, a cura di (2008) I distretti rurali in Calabria Università degli Studi Mediterranea di Regio. Dipartimento di Scienze e tecnologie Agro-forestali e Ambientali, Calabria

Hoffmann A (2008) I distretti rurali in Sicilia Università Di Palermo, Dipartimento di Economia dei Sistemi Agro-forestali. Fotograf, Palermo

lacoponi L (1990) Distretto industriale marshalliano e forme di organizzazione delle imprese in agricoltura in Rivista di Economia Agraria Anno XLV, n.4 pp 712-734 n. 4, Franco Angeli, Milano. ISSN 0035-6190

lacoponi L (2001) Distrettualità agricola: una difficile (e breve) navigazione tra opposti paradigmi economici in La Questione Agraria n. 4:111-118, Franco Angeli, Milano, ISSN: 1593-8441

lacoponi L (2002) Dal distretto agricolo al distretto rurale in Valorosi F. (a cura di), Lo sviluppo del sistema agricolo nell'economia post-industriale: Franco Angeli, Milano

Lee J., Arnason A., Nightingale A., Shucksmith M (2005) Networking: social capital and identities in European rural development. Sociologia ruralis, 45 (4):269-283 ISSN: 1467-9523

Maizza A (2010) I Distretti Agroalimentari nel Contesto Globale. Un'analisi sul Territorio Pugliese. Franco Angeli, Milano, ISBN: 9788856836462

Marangon F (2008a) Aspetti economici per l'individuazione di un Distretto Rurale nel territorio della Pianura Friulana, CCIAA di Udine, Convegno Ipotesi di un distretto per lo sviluppo rurale della Bassa Pianura friulana, Agriest Udine, 28 gennaio

Marangon F (2008b) Lo sviluppo rurale sostenibile in Friuli Venezia Giulia: tra distretti rurali e distretti di economia solidale, Seminario L'economia locale per lo sviluppo del territorio. Università degli Studi di Scienze Gastronomiche, Pollenzo (Cn)

Mollard A (2001) Qualité et développement teritorial: une grille d'analyse théorique à partir de la rente. In: Économie rurale. №263, 2001. pp. 16-34. DOI: 10.3406/ecoru.2001.5240, http://www.persee.fr/web/revues/home/prescript/ issue/ecoru_0013-0559_2001_num_263_1

Montresor E (2000) I sistemi locali di produzione agroalimentare CNEL, Secondo rapporto sull'agricoltura. L'agricoltura tra locale e globale. Distretti e filiere. Collana Documenti CNEL, II serie. N.23,Roma 
Montresor E., Pecci F., Pontarollo N. (2011) Distretti agroalimentari di qualità e processi di governance locale: due regioni a confronto in Agriregionieuropa, Anno 7, n. 24 pp 57-61. ISSN: 1828 - 5880

Murdoch J (2000) Networks - a new Paradigm for Rural Development? J Rural Studies 16(4):407-419, http://dx.doi.org/ 10.1016/S0743-0167(00)00022-X

Musotti F (2001a) II territorio: da sempre nell'analisi economico-agraria italiana La Questione Agraria, n. 4:119-131, Franco Angeli, Milano, ISSN: 1593-8441

Musotti F (2001b) II "nuovo" orientamento dell'agricoltura italiana: riscoperta del territorio, ruralità, distrettualizzazioni Sviluppo locale, VII, 17:79-91, Rosenberg \& Sellier, Torino. ISSN:1974-2193

Oxford Research AS (2008) Cluster policy in Europe Oxford research AS, January http://www.clusterobservatory.eu/ system/modules/com.gridnine.opencms.modules.eco/providers/getpdf.jsp?uid=100146

Pacciani A (1997) II progetto "Maremma Distretto Rurale d'Europa" Atti dell'Accademia dei Georgofili, Anno 1997, vol XLIV. Industrie Grafiche Fiorentine, Firenze

Pacciani A (2002a) II Distretto rurale della Maremma: dalla proposta alla realizzazione Atti dell'Accademia dei Georgofili, Anno 2002, settima serie, vol XLIX. Industrie Grafiche Fiorentine, Firenze

Pacciani A (2002b) Funzioni sociali dell'agricoltura e nuovi strumenti di intervento pubblico XXXIX Convegno SIDEA. "Nuove tipologie dellimpresa nell'agricoltura italiana", 12-13 settembre, Firenze

Pacciani A (2003) La Maremma Distretto Rurale: un nuovo modello di sviluppo nella consapevolezza della propria identità. Editrice II mio Amico. Grosseto

Pacciani A Toccaceli D (2010) Territorio, imprese e istituzioni nella PAC oltre il 2013: I'agricoltura grossetana di fronte a nuovi scenari, In:Pacciani A. Toccaceli D. (Eds), Le frontiere dello sviluppo rurale. L'economia grossetana tra filiere e territorio Milano: Franco Angeli ISBN: 978-88-568-3268-6

Pacciani A., Toccaceli D (Eds) (2014) Percorsi di governance per la valorizzazione delle aree rurali nella prospettiva di riforma delle politiche europee I Georgofili Quaderni 2013-II Società Editrice Fiornetina, Firenze ISBN: 978-88-6032-294-4

Pecqueur B (2001) Qualité et développement territorial: I'hypothèse du panier de biens et de services territorialisès. Économie Rurale. 261: 37-49. doi: 10.346/ecoru.2001.5217, http://www.persee.fr/web/revues/home/prescript/article/ ecoru_0013-0559_2001_num_261_1_5217

Perrier-cornet P., Sylvander B (2000) Firmes, coordinations et territorialité. Une lecture économique de la diversité des filières d'appelation d'origine In: Economie Rurale 258:78-89, pp78-89. DOI: 10.346/ecoru.2000.5195. http://www. persee.fr/web/revues/home/prescript/article/ecoru_0013-0559_2000_num_258_1_5195

Petrovich B, Manzoni P (2010) I distretti nella regione Lombardia. Rete Rurale Nazionale, Roma

Porter M. E. (1998) Clusters and the new economics of competition In: Harvard business review 76(6):77-90. ISSN 0017-8012

Porter E (2003) The economic performance of Regions, In: Regional Studies, Vol. 37.6\&7, pp549-578, August-October DOI: 10.108/0034340032000108688

Porter M., Ketels C (2009) Clusters and industrial districts: common roots, different perspectives in Becattini G., Bellandi M., De Propris L. (Eds) A handbook of industrial districts, Edward Elgar, Cheltenam UK, Northampton, MA, USA:172-183 ISBN : 978-1-84720-267-3

Porter M.E., Ketels C., Miller K., Bryden R (2004) Competitivness in rural U.S. Regions: Learnings and research agenda, U.S. Economic Development Administration, February 25, 2004 http://www.hbs.edu/faculty/Pages/item.aspx? num $=46871$

Pyke F., Becattini G., Sengenberger W. (eds) (1990) Industrial districts and inter-firm Co-operation in Italy, IILS, ILO, Geneva

Ray C (1998) Culture, Intellectual Property and Territorial Rural Development. In: Sociologia Ruralis, vol 38, issue 1. doi: $10.1111 / 1467-9523.00060$

Regione A bruzzo Agenzia Regionale Servizi Sviluppo Agricolo (1999) II distretto agroindustriale della Marsica. Grafiche Di Censo, Avezzano

Romano D (2000) I sistemi locali di sviluppo rurale CNEL, Secondo rapporto sull'agricoltura. L'agricoltura tra locale e globale. Distretti e filiere. Collana Documenti CNEL, II serie. N.23, Roma

Rouger M.P. (2014) Pays de fougeres ECOBATYS: De l'observatoire à la demarche de prospective In: Pacciani A. Toccaceli D (Eds) Percorsi di governance per la valorizzazione delle aree rurali nella prospettiva di riforma delle politiche europee, pp51-60, I Georgofili Quaderni 2013-II Società Editrice Fiornetina, Firenze ISBN: 978-88-6032-294-4

Saraceno E. (1992) II distretto delle barbatelle. La Questione Agraria, n. 46, pp.209-231 La questione agraria 46:209-231. Franco Angeli, Milano, ISSN: 1593-8441

Sforzi F (1987) L'identificazione spaziale In: Becattini G. (ed.) Mercato e forze locali: il distretto industgriale, II Mulino, Bologna.

Sforzi F., Mancini M. C. (2012) A reinterpretation of the agri-food system and its spatial dynamics through the industrial district In: Arfini F., Mancini M.C., Donati M., Local agri-food systems in a global world: market, social and environmental challenges, pp 9-27, Cambridge Scholars Publishing, Newcastle upon Tyne, UK ISBN (10): 1-4438-3664-8, ISBN (13): 978-1-4438-3664-7

Spampinato D., Timpanaro G (2012) La competitività dei sistemi produttivi territoriali in Sicilia: alcuni casi studio per un'analisi dei distretti agroalimentari in Economia e Diritto Agroalimentare n.1 Economia \& diritto agroalimentare XVII: 55-82. University Press, Firenze

Tarangioli S (2008), Rural and quality food districts as governance instruments: the Italian experience. WP presentato alla Conferenza Europea "Europe's rural areas in action. Facing the challanges of tomorrow. Cipro, 16-17 ottobre

Tarangioli S (2011) La progettazione integrata nelle colline del Medio Friuli, in: Seminario Nazionale su Politiche, istituzioni e sviluppo rurale:come migliorare i processi di governance. Rete Rurale Nazionale, Roma

Tinacci Mossello M (2002) Rischi di Crisi e Nuove Opportunità di Sviluppo per i Mercati Locali nel Quadro Della Globalizzazione. In: De Rosa M, de Vincenzo D (eds) Tra globalizzazione e localismo. Liguori Editore, Napoli, pp 33-50

Toccaceli D (2006) II Distretto rurale della Maremma: 1996-2006. Come si forma un Distretto rurale in Agriregionieuropa, Anno 2, n. 6 pp. 54-56, ISSN: 1828 - 5880

Toccaceli D (2012) Dai distretti alle reti? I distretti in agricoltura nell'interpretazione delle Regioni e le prospettive verso il 2020. Rete Rurale Nazionale, Roma, ISBN: 978-88-8145-235-4 
Toccaceli D (2014) Sustainable Development in Rural Areas: A Comparison on Governance Among Some European Experiences. In: De Gennaro BC, Nardone G (eds) Sustainability of the Agri-Food System: Strategies and Performances, Proceedings of the 50th SIDEA Conference, Lecce, Chiostro dei Domenicani. Universitas Studiorum, Mantova, pp 307-321, ISBN 978-88-97683-60-5

Tregear A., Arfini F., Belletti G., Marescotti A (2007) Regional foods and rural development: The role of product qualification In: Journal of Rural Studies, Vol. 23, Issue 1, Pages 12-22, Elsevier Ltd, doi:10.1016/j.jrurstud.2006.09.10

Submit your manuscript to a SpringerOpen ${ }^{\circ}$ journal and benefit from:

- Convenient online submission

- Rigorous peer review

- Immediate publication on acceptance

- Open access: articles freely available online

- High visibility within the field

- Retaining the copyright to your article

Submit your next manuscript at $\boldsymbol{\wedge}$ springeropen.com 